\title{
The Upper Palaeolithic at Trenčianske Bohuslavice, Western Carpathians, Slovakia
}

Jarosław Wilczyński, Ondrej Žaár, Adrián Nemergut, Bernadeta KufelDiakowska, Magdalena Moskal-del Hoyo, Przemysław Mroczek, Barna PállGergely, Tomasz Oberc \& György Lengyel

To cite this article: Jarosław Wilczyński, Ondrej Žaár, Adrián Nemergut, Bernadeta KufelDiakowska, Magdalena Moskal-del Hoyo, Przemysław Mroczek, Barna Páll-Gergely, Tomasz Oberc \& György Lengyel (2020) The Upper Palaeolithic at Trenčianske Bohuslavice, Western Carpathians, Slovakia, Journal of Field Archaeology, 45:4, 270-292, DOI: 10.1080/00934690.2020.1733334

To link to this article: https://doi.org/10.1080/00934690.2020.1733334

曲 Published online: 09 Mar 2020.

Submit your article to this journal $\pi$

Џlll Article views: 109

Q View related articles $₫$

View Crossmark data ¿` 


\title{
The Upper Palaeolithic at Trenčianske Bohuslavice, Western Carpathians, Slovakia
}

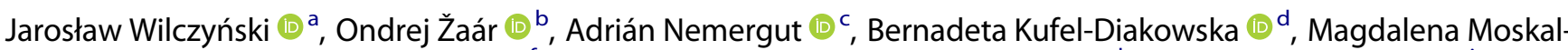

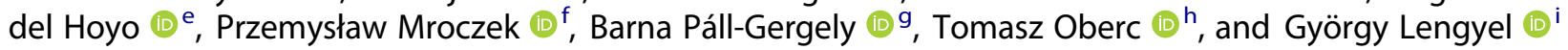

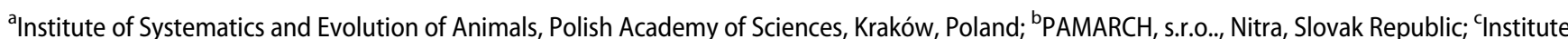 \\ of Archaeology, Slovak Academy of Sciences, Nitra, Slovak Republic; ${ }^{d}$ University of Wrocław, Institute of Archaeology, Wrocław, Poland; ${ }^{~} W$. Szafer \\ Institute of Botany, Polish Academy of Sciences, Kraków, Poland; Institute of Earth and Environmental Sciences, Maria Curie-Skłodowska University \\ Lublin, Poland; ${ }^{9}$ Plant Protection Institute, Centre for Agricultural Research, Budapest, Hungary; ${ }^{\text {h}}$ The Institute of Archaeology and Ethnology Polish \\ Academy of Sciences, Centre for Mountains and Uplands Archaeology, Kraków, Poland; 'University of Miskolc, Miskolc-Egyetemváros, Hungary
}

\begin{abstract}
Trenčianske Bohuslavice Gravettian site has been known since the early 1980s, with possibly the longest sequence of Upper Palaeolithic human occupation in the region, including a peculiar assemblage of lithic tools composed of bifacial leaf points. This paper presents the results of the 2017 excavation season that produced new data on the absolute chronology, stratigraphy, paleobotany, archaeology, and archaeozoology of the site. We found that the earliest occupation most probably belongs to the Aurignacian. This is followed by two Late Gravettian layers and the layer that yielded the bifacial leaf points. An Early Epigravettian layer dated to 26 kya seals the sequence. The succession of biological remains and geological evidence enabled the reconstruction of a cooling climate and disappearing boreal forest, which corresponded well with the development of the Last Glacial Maximum.
\end{abstract}

\section{KEYWORDS}

Late Gravettian;

Epigravettian; Last Glacial

Maximum; lithic armature;

bifacial leaf point

\section{Introduction}

Long Upper Palaeolithic (UP) archaeological sequences are rare for the Weichselian glacial period in eastern central Europe (ECE). The longest sequence of UP human occupation is from Willendorf II, Lower Austria, which consists of Early Aurignacian, Early Gravettian, Pavlovian, and Late Gravettian occupations between 43.5 and 27 kya (Otte 1981; Haesaerts et al. 1996; Moreau 2009; Nigst 2012; Nigst et al. 2014). In southern Moravia, the Dolní Věstonice brickyard also provides a long Weichselian stratigraphic sequence, but the number of multi-layered archaeological sites in the Pavlov Hills is small. The Pavlovian layers are sometimes underlain by uncharacteristic UP lithic assemblages contemporaneous with the Early Gravettian of Willendorf II, dated to 34 kya (Novák 2016; Svoboda 2016), without any traces of the Early Upper Palaeolithic (EUP) Aurignacian, and the human occupations at the Pavlovian sites halted before the Late Upper Palaeolithic (LUP) Epigravettian of the Last Glacial Maximum (LGM) (Klíma 1963, 1990; Svoboda 1997, 2005, 2007, 2016; Oliva 2009, 2016). Indeed, it is exceptional when a LUP layer seals a Middle Upper Palaeolithic (MUP) series of human occupation in ECE, and when it does so, then the EUP layer is missing, such as the case with the Gravettian-Epigravettian succession at Pilisszántó I rockshelter in Hungary (Dobosi and Vörös 1987; Lengyel 2016) or at Kašov I in eastern Slovakia (Novák 2004; Kaminská 2014). According to the available archaeological record (Bárta 1988; Vlačiky et al. 2013), the only site in ECE which may have contained occupations from each UP subperiod was found at the village Trenčianske Bohuslavice (hereafter abbreviated as $\operatorname{TrB}$ ) in western Slovakia.

Several excavation seasons were carried out at $\operatorname{TrB}$ in the 1980s (Bárta 1988), and a test pit was made in 2008 to retrieve controlled samples to clarify the stratigraphy of the site
(Vlačiky et al. 2013). The archaeological sequences recovered in the 1980s, which retrieved the majority of the finds known from the site, remained unclear due to the lack of published details necessary to understand the relation between assemblages excavated in different areas of the site. All human occupations were dated to the Gravettian period, including a bifacial leaf point (BLP) tool assemblage, which eventually resulted in a major inconsistency in the archaeological record of ECE, because BLPs had primarily been associated with the Szeletian culture prior to the discovery of the TrB site (Mester 2018). The Gravettian and the BLP assemblages were found $75 \mathrm{~m}$ apart from each other, and no stratigraphic correlation was made between the two areas, although the radiocarbon dates suggested contemporaneity between the two types of lithic industries. In spite of the ambiguous correlation, the $\operatorname{TrB}$ and other archaeological records suggested that BLPs are an integral part of the Gravettian technology (Simán 1990; Lengyel, Mester, and Szolyák 2016; Lengyel and Wilczyński 2018).

The fieldwork in 2008 was too limited to clarify the stratigraphic correlations between the excavation areas located $75 \mathrm{~m}$ apart; however, it achieved important results concerning archaeological, faunal, and botanical remains. The most interesting result was the discovery of an archaeological layer on the top of the Gravettian sequence (Vlačiky et al. 2013), which highlighted the possibility of finding an UP sequence at $\operatorname{TrB}$ almost as long as that at Willendorf II. This stratigraphy has the potential to illuminate cultural changes of hunter-gatherers in relation to the dynamic climate and environment of the last glacial period. In this paper, therefore, we present new data that clarifies the number of human occupations and the relevant archaeological cultures recovered at $\operatorname{Tr} B$, which contribute to our knowledge 
about the Upper Pleniglacial human occupation of eastern central Europe.

\section{Trenčianske Bohuslavice Site}

\section{Location}

Trenčianske Bohuslavice is a village situated in western Slovakia, in the Slovak-Moravian Carpathians, a part of the Outer Western Carpathians (Figure 1A-B). It is $14 \mathrm{~km}$ southwest of Trenčín, in the valley of the Bošáčka Stream, which is a western tributary of the Váh, the main river of this region. The opening of the Bošáčka valley from the Váh valley is narrow. The archaeological area is located outside of the center of the village and is called Pod Tureckom (Figure 1). Pod Tureckom was the local brickyard of the village until the late 1970s. Earthmoving at the brickyard uncovered mammoth remains in the early 20th century, and artifacts have been found since World War II (Bárta 1967, 1988). The archaeological site is found on the northern lower slopes of Turecký Vrch (Turkish Hill) (346 masl), directly behind the narrow pass of Bošáčka. The elevation of the site is $207.5-211$ masl, $10-15 \mathrm{~m}$ above the bottom of the Bošáčka Stream bed.

\section{Previous research}

The first set of excavations at the site were carried out between 1981 and 1986 (Bárta 1988). J. Bárta opened three areas to excavate, A, B, and C (Figure 2). Area A contained two sets of trenches placed $25 \mathrm{~m}$ apart from each other. In the first location of this area (A1), a large part of the sediment covering the archaeological layer was removed by bulldozer. In 1981, about $75 \mathrm{~m}$ westwards from area $\mathrm{A}$, a $7 \mathrm{~m}$ deep section was exposed in a deep gully running west-east, exposing the stratigraphy of the Pod Tureckom area. Area B was opened up from the stratigraphic section of the gully wall in 1982, oriented to the north. In 1983, a second set of trenches was excavated in A (area A2) west of the bulldozed area A1 (Bárta 1986). The third location, area C, was tested about $50 \mathrm{~m}$ north of area $\mathrm{A}$, but after yielding only a few archaeological finds, the excavation was not continued. Altogether, Bárta found four archaeological levels in the site's different excavation areas.

The uppermost archaeological level found in the 1980s, $70-90 \mathrm{~cm}$ under the surface in area A2, was classified as Gravettian. Animal bones, such as those from reindeer and horses, marked this layer in the stratum, and lithic artifacts were fewer than in other layers, but this layer contained a stone-paved hearth (Bárta 1988, fig. 9). Bárta marked this stratigraphic unit layer III (Figure 3A). The main Gravettian occupation (layer II) lay beneath layer III. According to Bárta (1988), these two layers were embedded within a calcareous loess formed during the Würm 3 stadial. Layer II yielded an abundant collection of knapped lithic artifacts. The third and lowermost archaeological layer (layer I) was below layer II. This layer was associated with the Würm 2-3 interstadial soil. Compared to layer II, layer I yielded fewer lithic artifacts, and animal bones were almost absent.

In area B, the human occupation was found $260-290 \mathrm{~cm}$ under the surface in a single layer. Area B was excavated through two trenches: $1 \mathrm{~B} / 82$ in 1982 and $2 \mathrm{~B} / 83$ in 1983 (Figure 2). The findings included lithic artifacts, animal bones, pierced quartzite pebbles, and hearths. The hearths in area $\mathrm{B}$ had been disturbed by solifluction (Figure 3B). The area B lithic tools' compositions differed from the compositions of areas A1 and A2 by containing bifacial leaf points (BLPs). However, no correlation was made between the layers of areas $\mathrm{A} 1, \mathrm{~A} 2$, and $\mathrm{B}$.

In 2008, Vlačiky and colleagues (2013) reopened $2 \mathrm{~m}^{2}$ in area A2 to collect samples for stable isotope analysis $\left({ }^{87} \mathrm{Sr} /{ }^{86} \mathrm{Sr},{ }^{13} \mathrm{C} /{ }^{12} \mathrm{C}\right.$, and $\left.{ }^{15} \mathrm{~N} /{ }^{14} \mathrm{~N}\right)$ of the paleontological remains and also to collect samples for radiocarbon dating

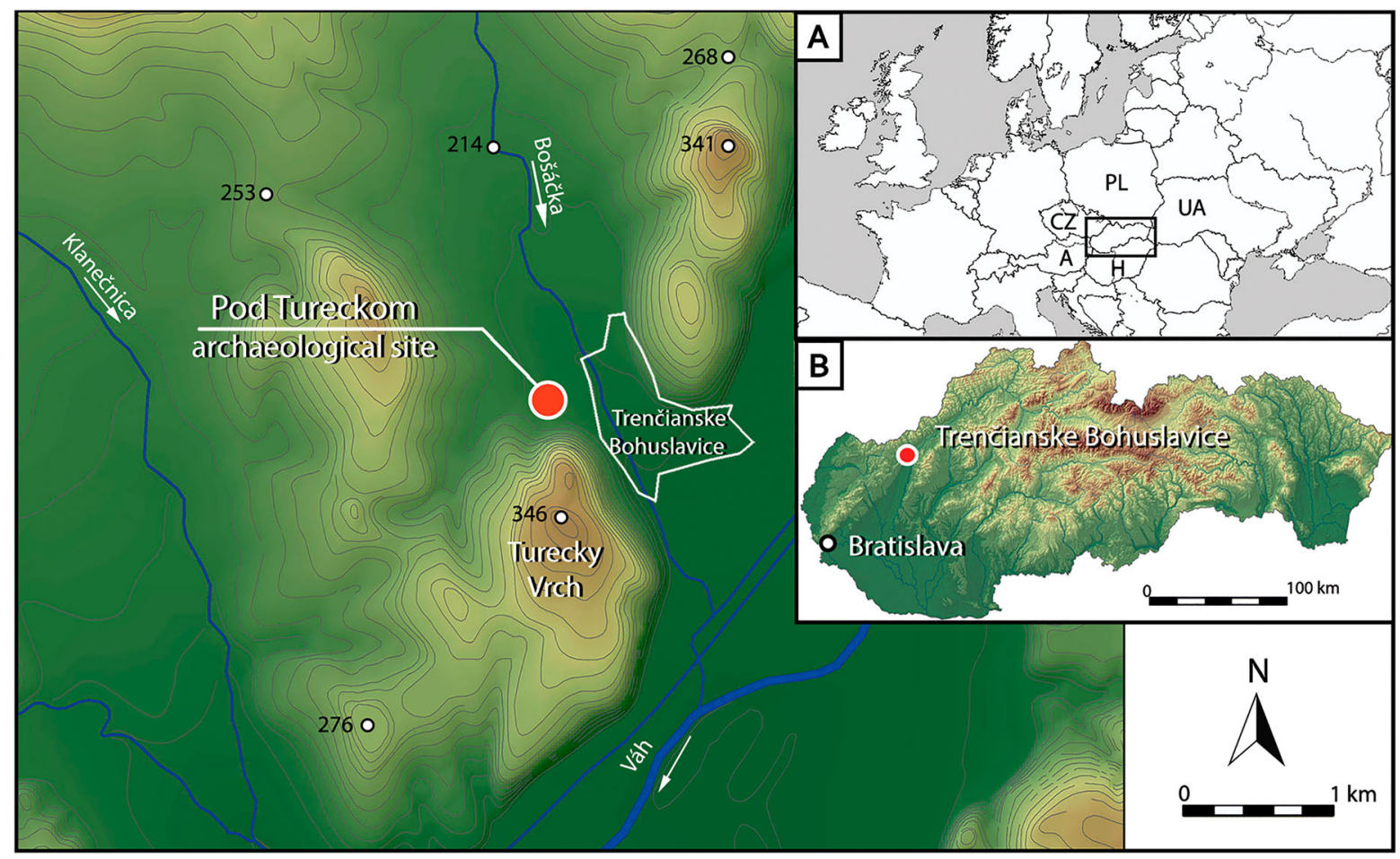

Figure 1. Location of the archaeological site (Pod Tureckom) at Trenčianske Bohuslavice on a hypsometric map: A) Location of Slovakia (framed) in central Europe; marked are the countries bordering Slovakia; B) Enlarged area of Slovakia. 


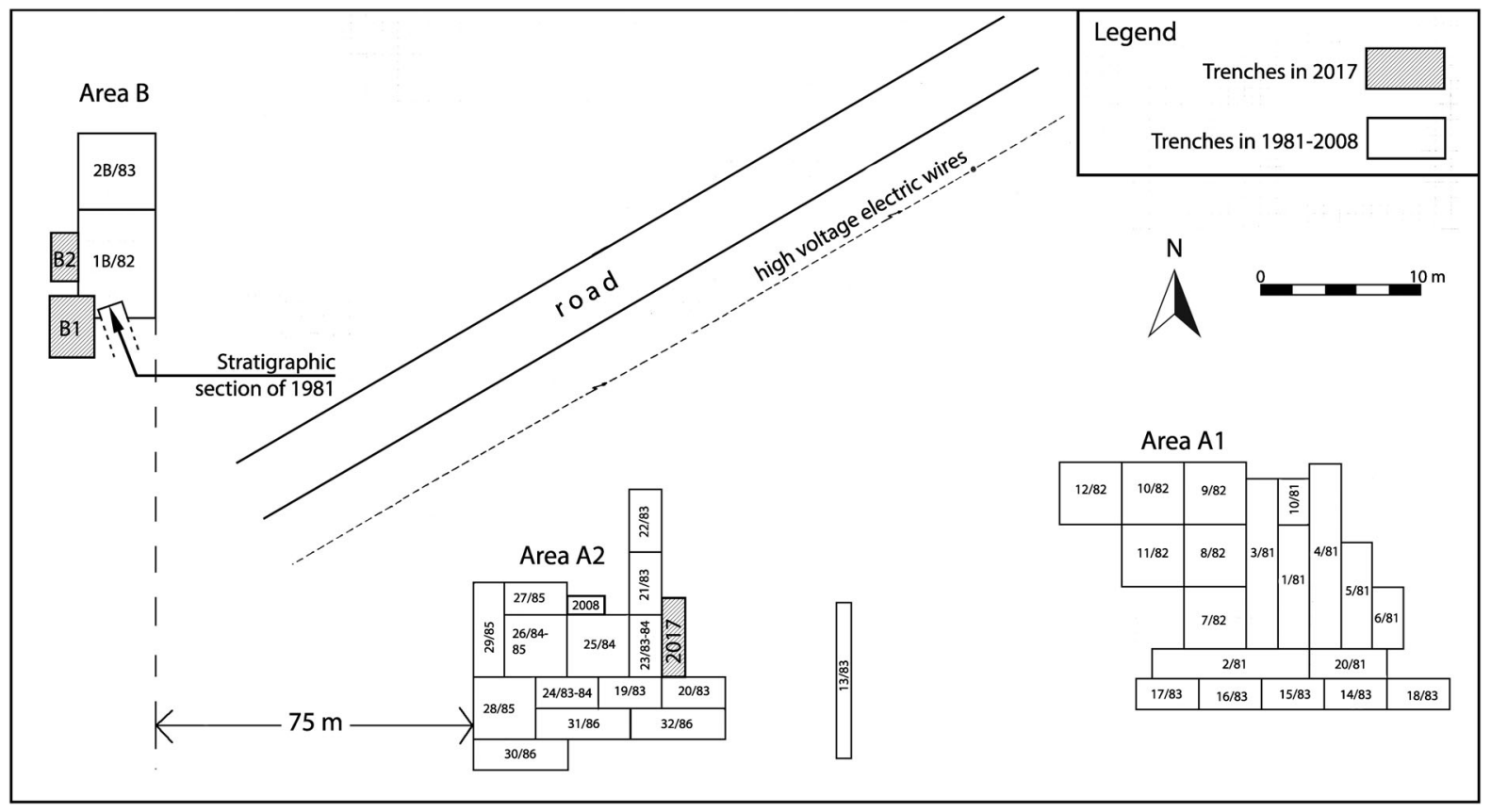

Figure 2. Excavation trenches at Trenčianske Bohuslavice.

and for sedimentological, malacozoological, palynological, and lithic studies. Vlačiky and colleagues (2013) found three archaeological layers in area A2 (Figure 3C). The uppermost layer (layer I) was between 25 and $35 \mathrm{~cm}$ below the recent surface, the second (layer II) between 55 and $65 \mathrm{~cm}$, and the third (layer III) between 85 and $110 \mathrm{~cm}$. The uppermost layer cannot be correlated with any layers in Bárta's stratigraphy. The second layer was equal to Bárta's layer III, due to the similar depth in area A2, the presence of animal bones, and the scarcity of lithics. The lowermost layer can be identified as Bárta's layer II, which yielded the greatest number of lithic artifacts.

\section{Radiocarbon dating results from previous research}

Radiocarbon dates were obtained from both former excavations (Table 1). Dates of the 1980s were obtained at the Gliwice Radiocarbon Laboratory, Poland, with the decay counting method. The first date that Bárta (1988) mentions in the publication of the site is $22,000 \pm 600$ B.P. (Ge-4009) from the archaeological layer of area $B$, which was obtained from charcoals of the distorted hearths (Figure $3 \mathrm{~B}$ ). The laboratory code "Ge" was given in error for Gliwice laboratory, correctly identified by Gd. A slightly different date with the same laboratory number is also given in the same paper, $22,500 \pm 600$ B.P., but this time with the correct laboratory code (Gd-4009). Bárta assigned this date to a stone structured hearth in area A2, trench 29/85, found in layer III of Bárta's division. However, the date Gd-4009 was obtained from a sample taken off the combustion features of area B (Figure $3 \mathrm{~B}$ ), according to the original submission sheets stored in the archives of the Gliwice Radiocarbon Laboratory. A few pages later in the same publication (Bárta 1988, 181), the date Gd4009 was correctly assigned to the BLP assemblage in area B.

The next date mentioned by Bárta (1988) is 20,300 \pm 500 B.P. (Gd-4011), obtained from trench 26-27/84-85 (area A2) on charcoals of a hearth situated $70 \mathrm{~cm}$ under the surface of Bárta's layer III (Figure 3A). The charcoals of this hearth were identified as Picea abies and other Pinopsida species (Bárta 1988).
Bárta's layer II was dated to $23,000 \pm 1300$ B.P. (Gd-4010) in trench 23/83 of area A2 via charcoals from a hearth. The charcoals were also of Picea abies and other Pinopsida species. No dates were eventually obtained for the lowest layer (layer I) embedded in the interstadial soil.

Verpoorte (2002) also obtained dates on charcoal collected by Bárta in the 1980s. A total of five dates were published (Table 1), along with a hitherto unmentioned date without trench number and depth data: $23,700 \pm 500$ B.P. (Gd-2490). According to the Gliwice Radiocarbon Laboratory Archives, the sample of this date derived from trench $28 / 85$ in area A2, $1.80 \mathrm{~m}$ below the surface. One of the dates was significantly older than the others: $29,910 \pm 260$ B.P. (GrA-16139). This date was assigned to trench IB/18 and obtained from a sample taken at $1.20 \mathrm{~m}$ under the modern surface. Such a trench number, however, did not exist, and there was no archaeological layer mentioned from this elevation in area $\mathrm{B}$. This date, however, could be associated with area $1 \mathrm{~B}$ and the digits " 18 " marking the year could have been inadvertently transposed instead of " 81 ", the year when the stratigraphic section in the gully wall was made in 1981 .

Vlačiky and colleagues (2013) published the third set of dates from area A2. The uppermost layer was dated to $22,330 \pm 110$ B.P. (GrA-42311), the second layer that equals Bárta's layer III was dated to $23,210 \pm 130$ B.P. (GrA-44244), and the lowermost layer that corresponds to Bárta's layer II was dated to $24,540 \pm 130$ B.P. (GrA-42312). Vlačiky and colleagues (2013) published two further dates yet unmentioned, making a reference to Žaár's (2007) unpublished dissertation, which were obtained from area B at a depth of $1.80 \mathrm{~m}(22,800$ \pm 600 в.P. [Gd-4016]) and from area A2, trench 29/85, a hearth at a depth of $0.90 \mathrm{~m}(23,400 \pm 700$ B.P. [Gd-4014]) (Figure 3A).

\section{Materials and Methods}

\section{Field methods}

Two areas of the site were excavated in 2017: A2 and B. In area A2, we opened a trench of $10 \mathrm{~m}^{2}$ in the unexcavated corner of 

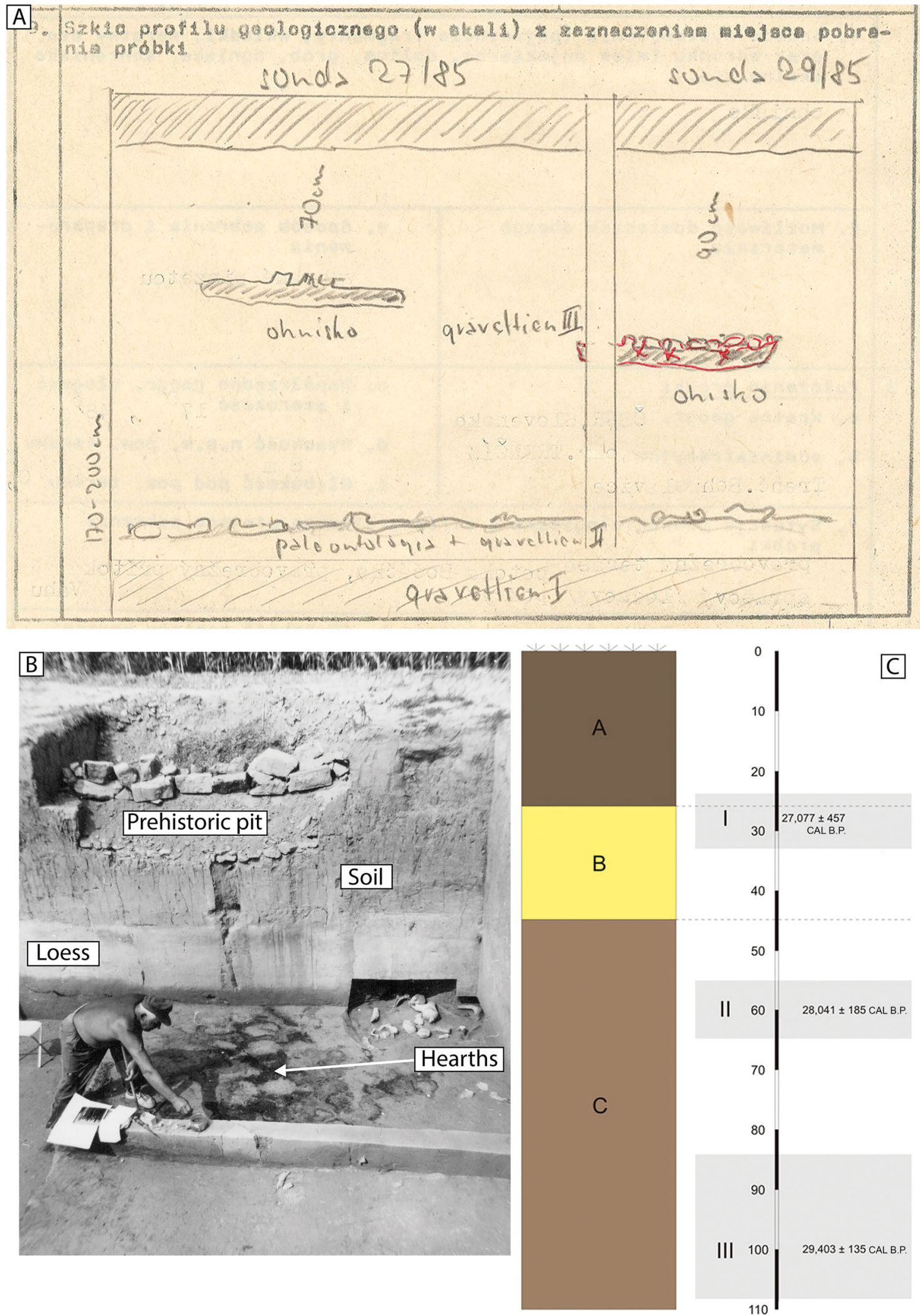

Figure 3. Previous stratigraphic sections at Trenčianske Bohuslavice: A) Sketch of archaeological layers in area A2. Marked are the hearths in the uppermost archaeological layer of the excavations in 1980 (archives of the Institute of Archaeology, SAS); B) Hearths of area 1B/82 in the stratigraphy (modified after Bárta 1988, fig. 6); C) The stratigraphy of the trench in 2008. Roman numerals mark the archaeological layers and capital letters are the geological units (modified after Vlačiky et al. 2013, fig. 4).

Bárta's trenches from 1983 (Figure 2). In area B, $18 \mathrm{~m}^{2}$ were exposed on the western edge of Bárta's trench $1 \mathrm{~B} / 82$ (Figure 2), and our trench B2 recovered the area under the prehistoric pit found by J. Bárta (Figure 3B). Recovery methods included hand-collection and wet-sieving using a mesh size of $1 \mathrm{~mm}$. The positions of archaeological finds and animal remains were recorded by total station (Geomax Zoom 30Pro2).

\section{Geology}

Descriptions of archaeological exposures were made on the basis of geological and paleopedological criteria. The subjects of the analysis were sediment-soil sequences available for direct studies in key sections. Their basic units were geological layers (loess) separated by soil and/or archaeological horizons. In 
Table 1. Radiocarbon dates of the site.

\begin{tabular}{|c|c|c|c|c|c|c|c|c|}
\hline Lab Code & Layer & Date & Std & Trench & CAL B.P. $95.4 \%$ & Sample & Origin & Reference \\
\hline GrA-42311 & $A 2-1$ & 22330 & 110 & 2008/B1 & $27,025-26,230$ & Charcoal & Arch. Layer & Vlačiky et al. 2013 \\
\hline Poz-97252 & $A 2-1$ & 22370 & 150 & 2017/A2 & $27,110-26,220$ & Charcoal & Hearth & This paper \\
\hline Gd-4011 & $A 2-2$ & 20300 & 500 & $27 / 85$ & $25,695-23,367$ & Charcoal & Hearth & Bárta 1988 \\
\hline GrA-16126 & $A 2-2$ & 23100 & 150 & $27 / 85$ & $27,662-27,126$ & Charcoal & Arch. Layer & Verpoorte 2002 \\
\hline GrA-44244 & $A 2-2$ & 23210 & 100 & 2008/B3 & $27,684-27,283$ & Charcoal & Arch. Layer & Vlačiky et al. 2013 \\
\hline Gd-4014 & $A 2-2$ & 23400 & 700 & $29 / 85$ & $29,036-26,191$ & Charcoal & Hearth & Bárta 1988 \\
\hline Gd-2490 & $A 2-2$ & 23700 & 500 & $28 / 85$ & $28,894-27,055$ & Charcoal & Arch. Layer & Bárta 1988 \\
\hline Poz-101182 & $\mathrm{A} 2-2$ & 23850 & 230 & $2017 / A 2$ & $28,447-27,574$ & Bone & Arch. Layer & This paper \\
\hline Poz-101178 & $A 2-2$ & 25130 & 270 & $2017 / A 2$ & $29,886-28,593$ & Bone & Arch. Layer & This paper \\
\hline Gd-4010 & $A 2-3$ & 23100 & 1200 & $23 / 83-84$ & $30,395-25,280$ & Charcoal & Hearth & Bárta 1988 \\
\hline GrA-42312 & $A 2-3$ & 24540 & 130 & $2008 / \mathrm{A} 3$ & $28,871-28,261$ & Charcoal & Arch. Layer & Vlačiky et al. 2013 \\
\hline GrA-16163 & $A 2-3$ & 25130 & 170 & $20 / 83$ & $29,584-28,764$ & Charcoal & Arch. Layer & Verpoorte 2002 \\
\hline Poz-101180 & $A 2-3$ & 25560 & 290 & $2017 / A 2$ & $30,544-29,007$ & Bone & Arch. Layer & This paper \\
\hline GrA-16162 & $A 2-3$ & 25650 & 160 & 24/1983-84 & $30,365-29,365$ & Charcoal & Arch. Layer & Verpoorte 2002 \\
\hline Poz-101181 & $A 2-3$ & 25910 & 300 & 2017/A2 & $30,810-29,435$ & Bone & Arch. Layer & This paper \\
\hline Poz-97362 & B-1 & 22180 & 220 & 2017/B2 & $27,042-25,984$ & Charcoal & Arch. Layer & This paper \\
\hline Gd-4009 & B-1 & 22500 & 600 & $\mathrm{~B} / 83$ & $27,836-25,720$ & Charcoal & Arch. Layer & Bárta 1988 \\
\hline Gd-4016 & B-1 & 22800 & 600 & 1B/1982 & $28,136-25,917$ & Charcoal & Arch. Layer & Bárta 1988 \\
\hline GrA-16161 & B-1 & 23280 & 140 & $2 B / 1983$ & $27,753-27,296$ & Charcoal & Arch. Layer & Verpoorte 2002 \\
\hline Poz-97254 & B-1 & 24560 & 180 & 2017/B2 & $28,994-28,158$ & Charcoal & Arch. Layer & This paper \\
\hline Poz-97253 & B-1 & 24600 & 180 & 2017/B2 & $29,046-28,203$ & Charcoal & Arch. Layer & This paper \\
\hline GrA-16139 & $?$ & 29910 & 260 & $1 \mathrm{~B} / 18$ & $34510-33605$ & Charcoal & $?$ & Verpoorte 2002 \\
\hline Poz-101822 & B-2 & 32790 & 460 & 2017/B1 & $38315-35887$ & Charcoal & Arch. Layer & This paper \\
\hline
\end{tabular}

addition, drilling has been carried out in each section to reach primary loess. For each part of the archaeological trenches, descriptions of key sequences were constructed. The following criteria were taken into account: lithology, structure, color, carbonate content, and the presence of $\mathrm{Mn}$ and Fe concentrations. In addition, three sections were sampled for particle size analysis at intervals of $10 \mathrm{~cm}$ (recent soil) and $5 \mathrm{~cm}$ (loess and archaeological layers). The grain size measurements were made based on the laser diffraction method (instrument Malvern Mastersizer 2000) according to the methodology described by Újvári and colleagues (2016).

\section{Dating}

Samples for radiocarbon dating were taken from each archaeological layer. Bones and charcoal were selected for dating. Charcoal was both hand-collected and floated from archaeological sediments through 0.5 and $1.0 \mathrm{~mm}$ mesh. Wood charcoal was identified taxonomically prior to radiocarbon dating. When possible, branch wood or twigs were selected, since this kind of wood might be an optimal material to avoid the old wood effect (Moskal-del Hoyo and Kozłowski 2009; Nowak et al. 2017).

The AMS radiocarbon dating was performed at Poznan Radiocarbon Laboratory. Methods of chemical pre-treatment at Poznan Laboratory are available online (Goslar 2015), according to which the lab follows the protocol of the Oxford Radiocarbon Accelerator Unit (Brock et al. 2010). Extraction of bone collagen was performed according to Piotrowska and Goslar (2002). Bone samples were regarded as suitable for collagen dating if nitrogen content was not lower than $0.6 \%$ and the $\mathrm{C} / \mathrm{N}$ ratio was within the interval of 2.7-3.5. The AMS dating procedure followed Czernik and Goslar (2001). Content of ${ }^{14} \mathrm{C}$ was measured using a $0.5 \mathrm{MV}$ NEC machine (Goslar, Czernik, and Goslar 2004). Radiocarbon dates were calibrated with OxCal (Reimer et al. 2013), indicating 95.4\% probability.

\section{Paleobotany}

The present study analyzed floated samples of a total volume of 126 liters of sediment, using meshes of 0.5 and $1.0 \mathrm{~mm}$, and manually collected samples. Charred wood anatomy was studied applying a reflected light microscope with magnifications of 100,200 , and 500 to observe three anatomical sections of the wood: transverse section, longitudinal radial section, and longitudinal tangential section in freshly broken charcoal fragments. Taxonomical identifications were made by comparing the specimens with the modern wood collections of the Department of Paleobotany of the W. Szafer Institute of Botany PAS and atlases of wood anatomy (Greguss 1955; Schweingruber 1990). The charcoal of Pinus type sylvestris-mugo was identified based on the presence of large fenestriform pits and ray tracheids with dentated walls in cross-fields, while the identification of Pinus cembra was based on the presence of large fenestriform pits and ray tracheids with smooth walls in cross-fields. Badly preserved charcoals with large fenestriform pits were recognized as Pinus sp. Based on wood anatomy, it was not possible to distinguish between two genera, Picea and Larix, and thus both genera are identified to one taxon. Coniferous wood, without specifying the species, was indicated when details of cross-fields could not have been observed due to the poor state of preservation.

Additional dendrological analysis focused on ring curvature observations was performed (Marguerie and Hunot 2007), and the presence of decayed wood was noted (Moskal-del Hoyo, Wachowiak, and Blanchette 2010). Charcoal fragments were also investigated using a scanning electron microscope (SEM Hitachi S-4700) at the Laboratory of Field Emission Scanning Electron Microscopy and Microanalysis at the Institute of Geological Sciences of the Jagiellonian University (Kraków, Poland).

\section{Malacology}

Snail shells were identified to species level whenever possible. Nomenclature followed Welter-Schultes (2012). Pupilla pratensis (Clessin, 1871) was not distinguished from Pupilla muscorum (Linnaeus, 1758) until recently (von Proschwitz et al. 2009). Due to their close conchological similarity, we treated all P. muscorum-like shells as P. muscorum. Ecological information on each species followed Ložek (1964), Kerney, Cameron, and Jungbluth (1983), Meng and Hoffmann (2009), Welter-Schultes (2012), and Horsák, Juřičková, and Picka (2013). 
Table 2. Litho- and pedological characteristics of trenches $A 2, B 1$, and B2.

\begin{tabular}{|c|c|c|}
\hline Depth (m) & Description & $\begin{array}{l}\text { Interpretation (soils/ } \\
\text { archaeological layers) }\end{array}$ \\
\hline \multicolumn{3}{|c|}{ Trench A2 section (north wall) } \\
\hline $0.0-0.17$ & Clayey loam, grey-yellow, $\mathrm{HCl}++$, sharp limit in color & Soil horizon Ap \\
\hline $0.17-0.80$ & $\begin{array}{l}\text { Calcareous loess with numerous pseudomycelium and molluscs, } \mathrm{HCl}+++ \text {, clear boundary, includes layer } \mathrm{A} 2-1 \\
\text { and } \mathrm{A} 2-2\end{array}$ & Soil horizon $\mathrm{Ck}$ \\
\hline $0.80-0.95$ & Calcareous loam, light pale yellow, numerous bones and charcoals, $\mathrm{HCl}+$, sharp undulated boundary & Archaeological layer A2-3 \\
\hline $0.95-1.40$ & Calcareous loam, olive yellow, $\mathrm{HCl}+$, diffuse boundary & $\begin{array}{l}\text { Poorly developed soil (interstadial } \\
\text { rank) }\end{array}$ \\
\hline $\begin{array}{l}1.40-2.45 \\
\text { (drilling) }\end{array}$ & Massive calcareous loam, yellow-grey, fine iron hydroxide bands, $\mathrm{HCl}++$ & Aeolian-solifluction loess layer \\
\hline \multicolumn{3}{|c|}{ Trench B1 section (north wall) } \\
\hline $0.0-0.30$ & Clayey loam, brown-grey, overgrown with roots of modern plants, $\mathrm{HCl}-$, clear boundary & Soil horizon Ap \\
\hline $0.30-0.57$ & Silt loam, grey, numerous roots, tubules with coprolites, $\mathrm{HCl}-$, clear border & Soil horizon Et \\
\hline $0.57-1.10$ & Clayey loam, numerous roots and coprolites, compacted, cracks from drying, $\mathrm{HCl}-$, boundary visible in color & Soil horizon Bt \\
\hline $1.10-1.60$ & $\begin{array}{l}\text { Clayey loam, mosaic of brown and dark grey colors-marble with bioglifs, clay coatings-clear traces of } \\
\text { illuviation, lower boundary visible in color and presence of carbonates }\end{array}$ & Soil horizon BC \\
\hline $1.60-2.10$ & $\begin{array}{l}\text { Non-calcareous clayey loam, grey-yellow, numerous pseudomycelia (vertical) and nodule }(2-3 \mathrm{~mm}), \\
\text { numerous concretions of Fe and } \mathrm{MN}-\mathrm{Fe}(1-2 \mathrm{~mm} \text { in diameter), numerous biochannels with coprolites, } \mathrm{HCl}+\text {, } \\
\text { sharp border in color, manganese horizon at a depth of } 1.80-1.82 \mathrm{~m}\end{array}$ & Soil horizon C \\
\hline $2.10-2.70$ & $\begin{array}{l}\text { Silt loam, grey-dark yellow, pseudomycelia and nodule as above, in the lower part numerous and large } \\
\text { molluscs filled with soil-repellent material (average } 15-20 \mathrm{~cm} \text { ), although no artifacts were found here, this } \\
\text { layer corresponds with the upper cultural layer of area } \mathrm{B} \text { found in trench } \mathrm{B} 2, \mathrm{HCl}+\text {, clear boundary }\end{array}$ & Soil horizon Ab \\
\hline $2.70-2.90$ & Silt loam, grey-brown, $\mathrm{HCl}+$, diffuse boundary & Soil horizon Btb \\
\hline $2.90-6.25$ & $\begin{array}{l}\text { Calcareous loam, brown-grey, numerous channels with coprolites, the top includes archaeological layer B-2 } \\
\text { of area B }\end{array}$ & Aeolian-solifluction loess layer \\
\hline \multicolumn{3}{|c|}{ Trench B2 section (west wall) } \\
\hline $0.0-0.30$ & Clayey loam, brown-grey, $\mathrm{HCl}+$, clear boundary & Soil horizon Ap \\
\hline $0.30-0.35$ & Calcareous loam $\mathrm{HCl}+++$, clear boundary & Soil horizon $\mathrm{Ck}$ \\
\hline $0.35-1.15$ & $\begin{array}{l}\text { Clayey loam, brownish-red, intersected with vertical slits, overgrown, numerous channels, visible illuvial clay } \\
\text { coatings, } \mathrm{HCl} \text { - }\end{array}$ & Soil horizon Bt \\
\hline $1.15-1.55$ & Clayey loam, light brownish-red, numerous bioglyphs, $\mathrm{HCl}$-, boundary visible in carbonates & Soil horizon BC \\
\hline $1.55-2.10$ & $\begin{array}{l}\text { Calcareous clayey loam, at a depth of } 1.90-1.95 \mathrm{~m} \text { there is a manganese layer detected also in Trench B1 at a } \\
\text { depth of } 1.80-1.82 \mathrm{~m}, \mathrm{HCl}+\text {, clear boundary }\end{array}$ & Soil horizon $\mathrm{C}$, loess \\
\hline $2.10-2.60$ & Numerous artifacts, animal bones, charcoals, bioturbations, $\mathrm{HCl}+$ & $\begin{array}{l}\text { Archaeological layer } \\
\text { B-1 }\end{array}$ \\
\hline
\end{tabular}

Table 3. Trenčianske Bohuslavice lithic tool kit raw material composition.

\begin{tabular}{lcccccc}
\hline & $\mathrm{A} 2-1$ & $\mathrm{~A} 2-2$ & $\mathrm{~A} 2-3$ & $\mathrm{~B}-1$ & $\mathrm{~B}-2$ & Total \\
\hline Radiolarite & 8 & 43 & 303 & 77 & 1 & 432 \\
& $100.0 \%$ & $35.2 \%$ & $35.7 \%$ & $88.5 \%$ & $100.0 \%$ & $40.5 \%$ \\
Erratic flint & 0 & 67 & 462 & 9 & 0 & 538 \\
& $0.0 \%$ & $54.9 \%$ & $54.5 \%$ & $10.3 \%$ & $0.0 \%$ & $50.5 \%$ \\
Jurassic flint & 0 & 2 & 47 & 0 & 0 & 49 \\
& $0.0 \%$ & $1.6 \%$ & $5.5 \%$ & $0.0 \%$ & $0.0 \%$ & $4.6 \%$ \\
Obsidian & 0 & 4 & 22 & 0 & 0 & 26 \\
& $0.0 \%$ & $3.3 \%$ & $2.6 \%$ & $0.0 \%$ & $0.0 \%$ & $2.4 \%$ \\
Chert & 0 & 6 & 14 & 1 & 0 & 21 \\
& $0.0 \%$ & $4.9 \%$ & $1.7 \%$ & $1.1 \%$ & $0.0 \%$ & $2.0 \%$ \\
Total & 8 & 122 & 848 & 87 & 1 & 1066 \\
& $100.0 \%$ & $100.0 \%$ & $100.0 \%$ & $100.0 \%$ & $100.0 \%$ & $100.0 \%$ \\
\hline
\end{tabular}

\section{Archaeozoology}

The bone remains were identified applying a comparative collection of the Institute of Systematics and Evolution of Animals (Polish Academy of Sciences, Kraków) and published data (Gramova 1950; Pales and Garcia 1981a, 1981b). Two quantified calculations were made: NISP (Number of Identified Specimens) and MNI (Minimal Number of Individuals) (Klein and Cruz-Uribe 1984; Lyman 1994). All bone remains were subjected to detailed observations in order to identify impacts of humans, carnivores, rodents, and plant root activity (Sutcliffe 1970; Haynes 1980, 1983; Binford 1981; Shipman and Rose 1983; Shipman, Foster, and Schoeninger 1984; Olsen and Shipman 1988; Lyman 1994; Stiner et al. 1995; Bennet 1999; Théry-Parisot 2002; Villa, Bon, and Castel 2002). Each mark was examined under lowpower magnification.

\section{Lithic tools}

We studied 686 lithic tools discovered in areas A2 and B in the 1980s and 2017. The materials from area A1 were excluded because the bulldozer work truncated the sequence, and the lithics cannot be securely paired with archaeological layers. Lithic raw materials were identified macroscopically following Prrichystal (2013) and the Lithic Reference Collection of the Eötvös Loránd University of Budapest (Mester 2013).

A lithic tool is defined here as a knapped stone product whose edges were modified by retouching or burin spall removals. The tools were analyzed in terms of lithic raw material, blanks of the tools, typology, and use-wear. We differentiated raw materials by their type, which also provides information about their geographic origin. The blanks of the tools were classified as either blade, flake, or debris. The category blade includes the small specimens (bladelets).

The tools were divided into major type classes: end-scraper, burin, edge retouched tool, perforator, truncation, splintered tool, combined tool, knife, and armature. We included notched and denticulated artifacts within the group of edge retouched tools. The category of armatures was subdivided into points, backed, and backed-truncated artifacts. The points were further divided into the categories of Gravette/ microgravette point, fléchette, Vachons point, retouched point, and BLPs. BLPs included unfinished bifacial tools as well. The Gravette/microgravette definition here was restricted to those specimens having inverse flat basal or, rarely, distal retouch opposed to the backed edge (Lengyel 2016, 2018).

The use-wear analysis aimed at determining the function of the lithic tool. The microscopic analysis was carried out 
at the Laboratory of Archaeometry and Archaeological Conservation, Institute of Archaeology, University of Wrocław. An experimental collection of the laboratory and published results of the use-wear analyses were the references to identify wear traces. Scars were analyzed with the use of an Olympus SZX9 stereomicroscope (up to $\times 114$ magnification). Polish, edge rounding, and striations were identified under a Nikon ECLIPSE LV100 metallographic microscope ( $\times 50-500$ magnification). Prior to microscopic observations, the artifacts were cleaned in an ultrasonic tank.

\section{Results}

\section{Geology and stratigraphy}

In area A2, aeolian sediments lay directly under the thin, ploughed modern surface. The archaeological layers were embedded in loess and loess-like sediments, which, according to the grain size analyses, are typical aeolian periglacial formations. The content of the loess fraction $(20-50 \mu \mathrm{m})$ is variable and falls within the range of $25-40 \%$. The diversity of these sediments underlines the distinct variability of average grain size $(\mathrm{Md})$, which suggests these are stratified sediments composed mainly of silt and sand and are interpreted as redeposited aeolian-slope loess-like sediments.

The uppermost archaeological layer (A2-1) (Figure 4) was situated near the top of the calcaric loess (Figures 5, 6), marked by charcoal and $\mathrm{Mn}-\mathrm{Fe}$ and $\mathrm{Fe}$ oxide concretions, knapped lithics, and a hearth. The thickness of the layer was ca. $5 \mathrm{~cm}$. This layer was correlated with layer I of Vlačiky and colleagues (2013).

The second archaeological layer in area A2 (A2-2) lay 25 $\mathrm{cm}$ beneath layer A2-1, still in calcaric loess. This layer was correlated with Bárta's uppermost archaeological layer (layer III) and layer II of the excavation in 2008; similarly, the findings were mostly animal bones and a few knapped lithics. However, the level of layer A2-2 compared to the surface is $0.20 \mathrm{~m}$ higher than Bárta's layer III, which we explain with a reorganization of the terrain at Pod Tureckom that resulted in lowering the surface of the topsoil above sea level. Charcoal was sporadic, and the small concretions of iron oxide found in layer A2-1 were missing. This archaeological layer cannot be distinguished by geological data.
The third archaeological layer of area A2 (layer A2-3) was situated $25 \mathrm{~cm}$ beneath A2-2 in loess. Compared to A2-1, A2-3 was extremely abundant in charcoal, iron oxide concretions, hard-burnt loess fragments, animal bones, and knapped lithics. This layer can be correlated with the main Gravettian occupation of Bárta's excavation (layer II) and layer III of 2008 .

Our analysis of the geological section in area A2 obtained converging results with the 2008 fieldwork (Vlačiky et al. 2013). Our $5 \mathrm{~cm}$ interval sampling, however, provided more details on the sediment features.

We did not find Bárta's lowermost layer (layer I) in area A2.

In area $\mathrm{B}$, two trenches were opened, $\mathrm{B} 1$ and $\mathrm{B} 2$, separated by a $1 \mathrm{~m}$ thick unexcavated area. B1 was situated south of B2. In both trenches, the stratigraphy started with a well-developed zonal Luvisol type soil of Late Glacial-Holocene origin ca. $1.60 \mathrm{~m}$ thick, which preserved only the B and lower horizons, due to being truncated on the top (Figure 5). The border between the Luvisol and the underlying loess was very pronounced in the content of carbonates. The upper archaeological layer was found only in B2 (layer B-1) and correlated with Bárta's only archaeological layer in area B, which lay 2.60-2.90 m beneath the surface (Figure 3B). This layer was found 2.10-2.60 $\mathrm{m}$ below the surface in 2017; therefore, we suspect that a reorganization of the surface might have occurred since the 1980s. Layer B-1 was embedded in loess and marked by irregular charcoal bands, patches of burnt loess surfaces, scattered charcoal and iron oxide concretions, animal bones, and knapped lithics. The morphology of the archaeological layer basically indicates its development in the form of poorly developed soil with traces of local redeposition and allows the traces to be recognized as typical weakly developed soil units formed as gley cryosols in a periglacial environment. This layer is decalcified or weakly calcified. Its main features are root pseudomorphs, coprolites, and artifacts. Its color was sharply darker than the embedding sedimentary environment, showing the characteristics of gley (redoximorphic) processes. The activity of soil processes and slope deformations in this layer are confirmed by the analysis of grain size. The average grain size is clearly drifting within the archaeological layer, and it increases by leaps and bounds towards the uppermost horizon (Figure 7). The

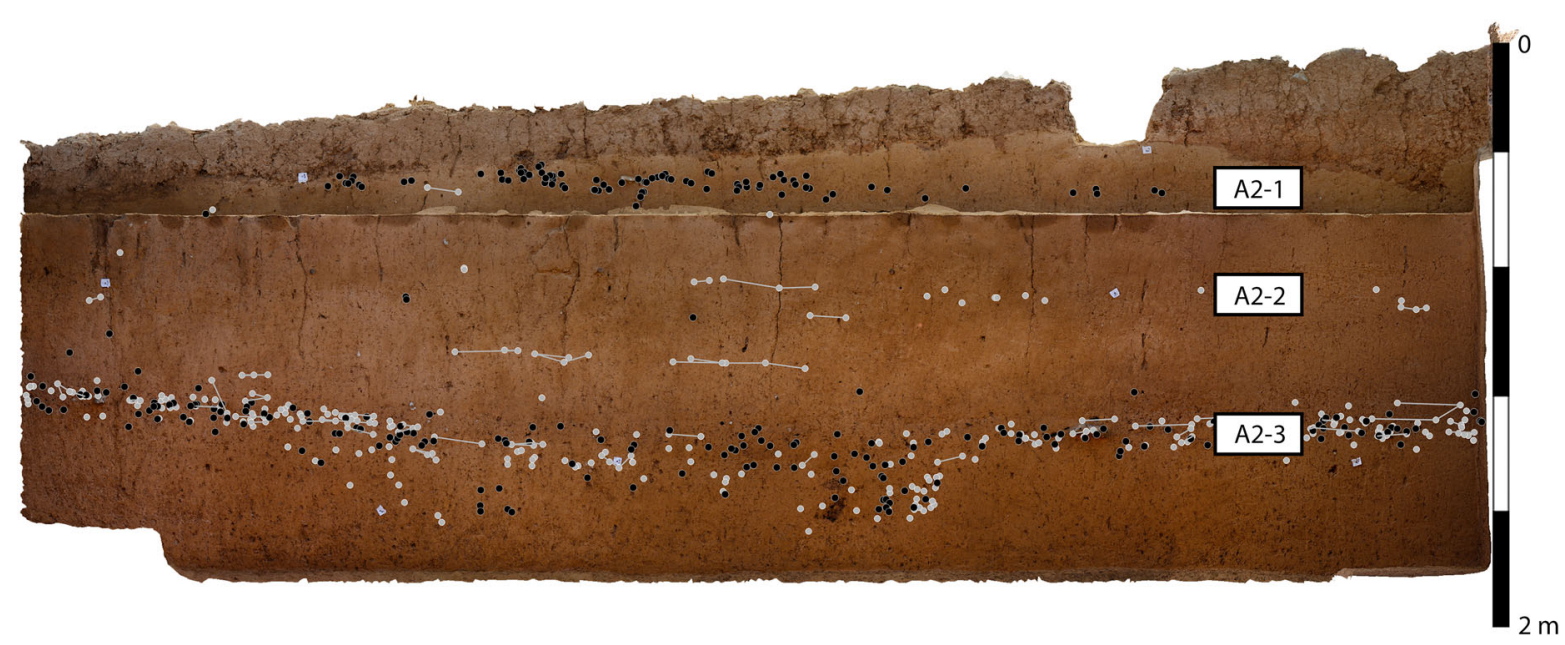

Figure 4. The eastern wall of A2 trench in 2017; marked are the positions of the archaeological layers. Black dots mark lithic finds, grey dots mark bones in the stratigraphy. Grey lines with grey dots mark bones of multiple measurements. 

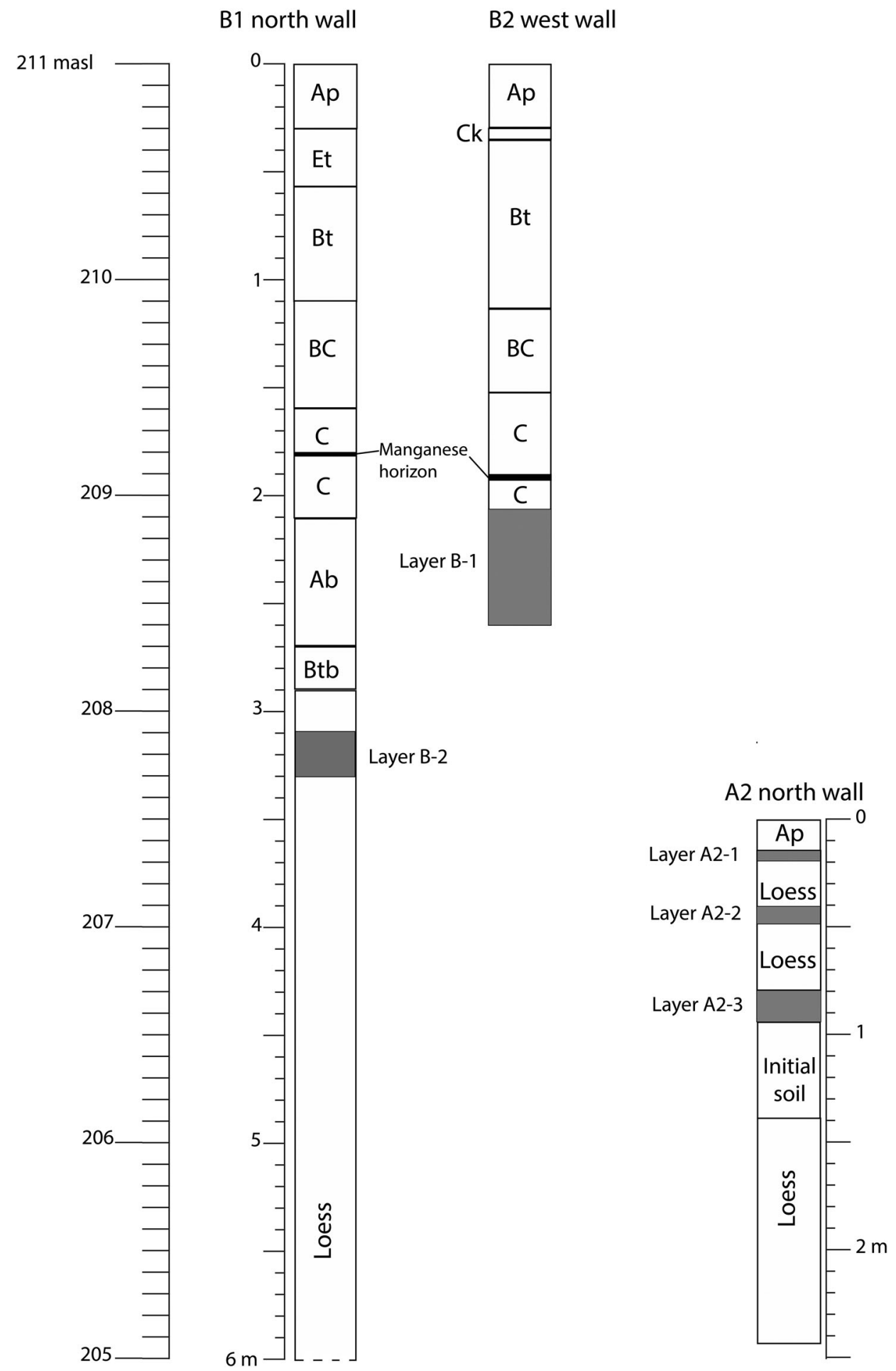

Figure 5. The correlation of the archaeological layers in areas A2, B1, and B2. Grey shades mark the archaeological layers.

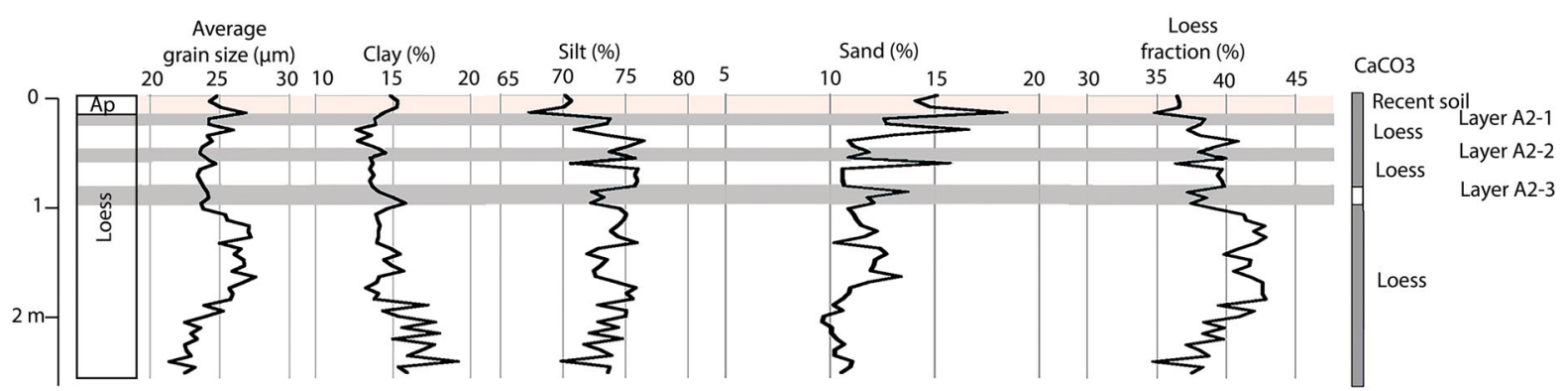

Figure 6. Results of the sedimentological analyses in trench A2. 


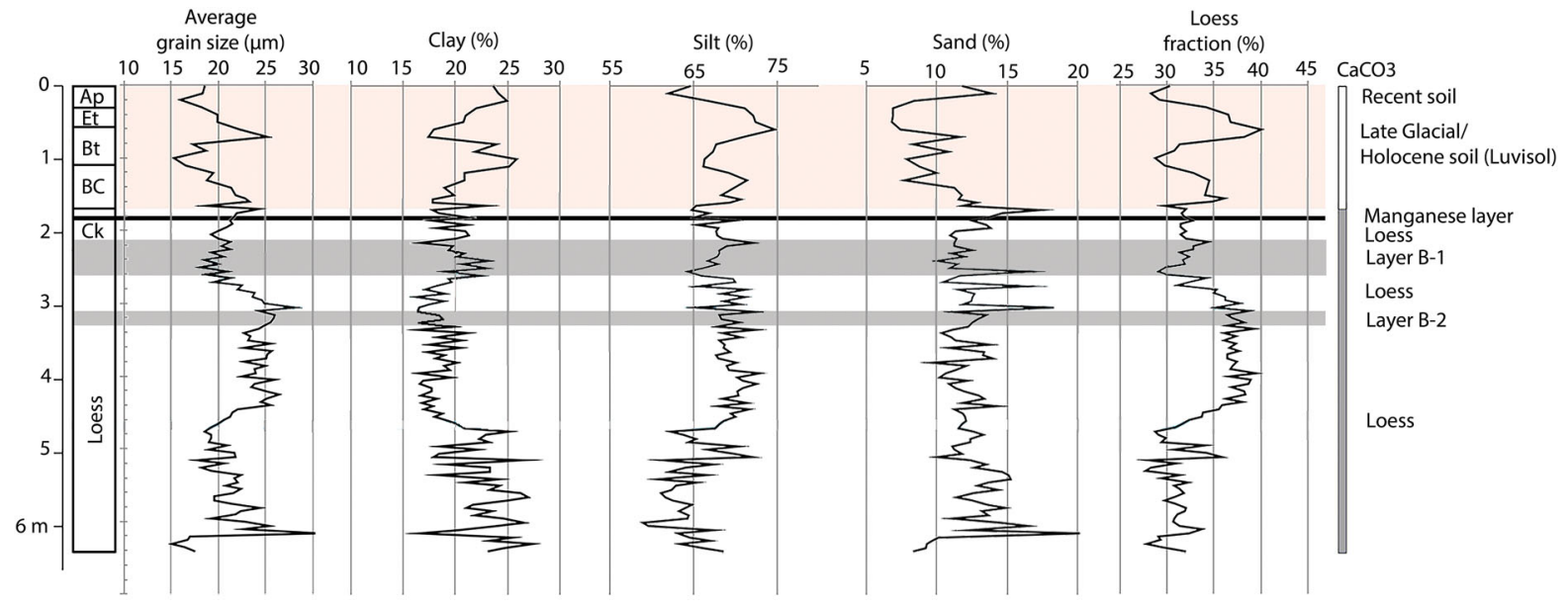

Figure 7. Results of the sedimentological analyses in trench B1.

activity of aeolian processes is reflected by the peaks of increased sand accumulation.

The lower layer of area B, layer B-2, was found in trench $\mathrm{B} 1$ (Figure 5), $1 \mathrm{~m}$ south of the excavation limit of B2, about $0.50 \mathrm{~m}$ beneath layer B-1. Layer B-2 (Figure 8) was a weakly developed soil marked with a few archaeological remains, including charcoal and knapped lithics. This layer was not mentioned in reports from work in the 1980s. Based on the similar geological positions, this could tentatively be correlated with the lowermost archaeological layer of the 1980s (layer I) situated in area A1 under the main Gravettian occupation (layer II) in an interstadial soil.

The correlation of the stratigraphic sequences between area A2 and area B is not straightforward, because the top of the section in area A2 was truncated down to the aeolian sediment. A fixed stratigraphic marker can be the interstadial soil under A2-3, which corresponds with the soil in B that contained the lower archaeological layer (B-2). According to this position, A2-3 is younger than B-2. Further correlations can be achieved relying on other data.

\section{Chronology}

Nine new dating samples were obtained from the 2017 excavation (Table 1). Layer A2-1 was dated to $22,370 \pm 150$ B.P. (Poz-97252) on the basis of a charcoal of Pinus sylvestrismugo taken from a hearth. Layer A2-2 was dated to 23,850 \pm 230 B.P. (Poz-101182), as derived from a Mammuthus primigenius rib fragment, and 25,130 \pm 270 B.P. (Poz-101178), as derived from a piece of mammoth vertebra. Layer A2-3 dates were also made on bones: $25,560 \pm 290$ B.P. (Poz-101180) was measured on a Rangifer metacarpal bone, and a date of 25,910 \pm 300 B.P. (Poz-101181) was from a Rangifer radius bone.

Concerning layer B-1, all bone samples failed to yield a sufficient amount of collagen. However, charcoal samples taken from three charcoal bands (Figure 9), each separated by a ca. $10 \mathrm{~cm}$ thick loess layer, yielded three dates. The charcoals were of Pinus sp. (Poz-97362), Picea sp./Larix sp. (Poz97254), and a coniferous tree (Poz-97253). From within the second band (middle), remains of twigs were dated. The stratigraphic order of the dates is reversed. The lowest date, $22,180 \pm 220$ B.P. (Poz-97362), is significantly younger than the two others above this: $24,560 \pm 180$ B.P. (Poz-97254) and 24,600 \pm 180 B.P. (Poz-97253). Layer B-2 was dated on a Picea sp. or Larix sp. charcoal to $32,790 \pm 460$ B.P. (Poz101822).

All radiocarbon dates obtained from the two areas of the site are divided among five layers. The first three are located in area A2, and they have a direct superposition. The fourth and fifth layers are in area B. Plotting the dates with $95.4 \%$ probability after calibration with OxCal (Reimer et al. 2013) in B.P. years shows a tendency for aging towards lower stratigraphic positions in area A2 (Figure 10).

The age 22,370 \pm 150 B.P. (Poz-97252) of Pinus sp. of layer $\mathrm{A} 2-1$ is identical to the $22,330 \pm 110$ B.P. (GrA42311) obtained by Vlačiky and colleagues (2013) for the same layer. Below, in layer A2-2, however, there is one outlier date of $20,300 \pm 500$ B.P. (Gd-4011). In layer A2-3, there is one insecure date, Gd-4010, that has a large standard deviation of 1300 radiocarbon years. Removing these dates from the list, we see that the most probable age of the uppermost occupation (layer A2-1) after calibration is $26-27$ kya. Layer A2-2 is dated to 27-28 kya, and layer A2-3 dates to 28-30 kya.

In area $\mathrm{B}$, two of the new dates are significantly older than the rest of the dates. If we disregard these two outliers, the age of the B-1 human occupation is most likely dated to 26-27 kya. The uppermost charcoal sample dated among the three (Poz-97253) was situated about $7 \mathrm{~cm}$ higher in the stratigraphy than the uppermost BLP specimen, and no BLP was found below the lowermost date. Therefore, we find an association between BLPs and the charcoal bands which eventually seem to be related with the periphery of the distorted hearth features of Bárta (Figure 3B). The reverse order of dates from the microstratigraphy of the 2017 excavation might have been caused by the redeposition of an older sediment over a later one, which may occur frequently in a slope position in a periglacial environment (Händel 2017), such as the case of layer B-1. Taking into account the movement of sediment, we estimate layer $\mathrm{B}-1$ to postdate layer A2-2 and predate layer A2-1.

\section{Charcoal analysis}

Layer A2-1 contained a very small number of charcoal fragments associated with a hearth. Only remains of Pinus t. sylvestris-mugo were identified $(\mathrm{n}=8)$. In layer A2-2, Picea sp. or Larix sp. were found $(\mathrm{n}=13)$ dispersed within the layer. Layer A2-3 yielded Pinus cembra $(\mathrm{n}=41)$, Pinus 


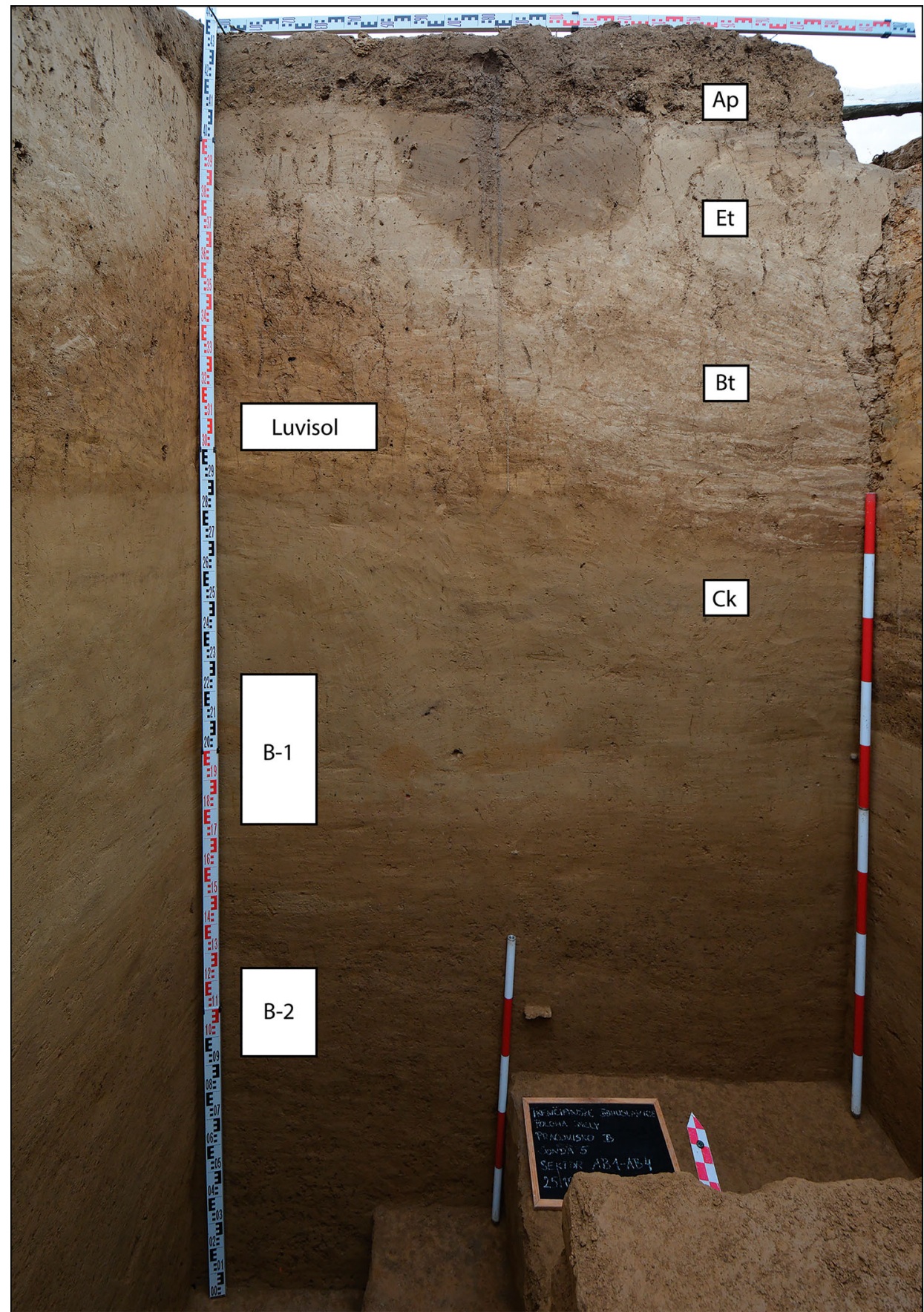

Figure 8. The development of loess-soil sequence and the position of archaeological layers B-1 and B-2 in trench B2 in 2017.

sp. $(\mathrm{n}=39)$, Picea sp. or Larix sp. $(\mathrm{n}=141)$, and coniferous wood $(\mathrm{n}=47)$. The most abundant samples came from a hearth of layer A2-3 $(n=207)$, and in this context, the remains of Picea sp. or Larix sp. were dominant $(n=117)$. With the exception of hearth remains, all other charcoal assemblages contained very small charcoal fragments that usually did not exceed 2-3 $\mathrm{mm}$ in transverse section. Charcoal of layer A2-3 was infected by fungi and xylophagous insects. Some of them had originated from branchwood, as they were characterized by the presence of compression wood; some twigs were documented, as well. The majority of Picea sp. or Larix sp. fragments had narrow rings. Fragments of bark were also found.

The layer B-1 charcoal assemblage included Pinus cembra ( $\mathrm{n}=21)$, Pinus sp. $(\mathrm{n}=27)$, Picea sp. or Larix sp. $(\mathrm{n}=98)$, and coniferous wood $(n=34)$. These samples were also frequently infected by fungi. Layer B-2 yielded only Picea sp. or Larix sp. $(n=5)$. They were characterized by the presence of fungi.

\section{Malacology}

Of the 7058 shells, 6987 specimens were identified to species level, divided among 17 species (Ložek 1964; Welter-Schultes 2012). The most dominant species were Pupilla muscorum (Linnaeus, 1758) $(\mathrm{n}=4116)$ and Succinella oblonga (Draparnaud, 1801) $(\mathrm{n}=1732)$ (Figure 11$)$; both taxa inhabit relatively dry, open areas, although they have a wide ecological tolerance. Therefore, their role in reconstructing habitat and climate is moderate.

The layer B-1 snail faunal assemblage $(n=1476)$ is divided among twelve species, and its spectrum of species is most similar to that of layer A2-1 $(\mathrm{n}=3734)$ (Figure 11), with the occurrence of Pupilla loessica (Ložek, 1954), Clausilia dubia Draparnaud, 1805, Vallonia tenuilabris (Braun, 1843), Trochulus hispidus (Linnaeus, 1758), and Columella columella (G. von Martens, 1830) in both layers. These 


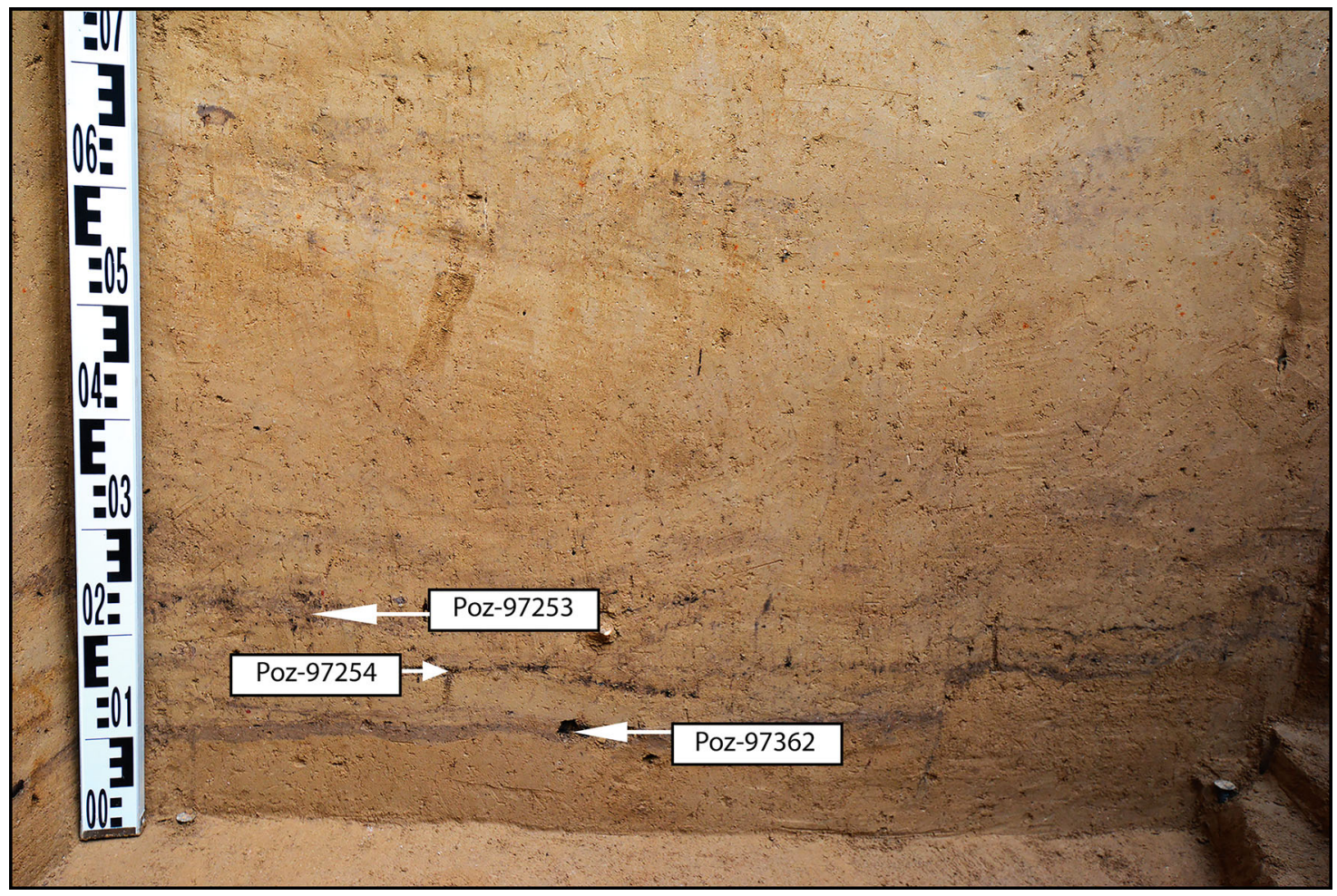

Figure 9. The three charcoal bands in the western wall, trench B2. Indicated are the origins of the radiocarbon samples.

species are absent or relatively rare in other layers. The most conspicuous difference between layers $\mathrm{B}-1$ and $\mathrm{A} 2-1$ is the frequency of Pupilla sterrii (Forster, 1840) in the former (n $=40)$ and Columella columella in the latter $(n=39)$. Both species prefer cold climates, and therefore the two species have minor importance in terms of differentiating climate reconstructions for the two layers. A single shell of Orcula dolium (Draparnaud, 1801), which is primarily a forest species, was found in layer A2-1, too.

The layer A2-2 snail faunal collection $(n=1587)$ consists of ten species whose presence indicates the driest climate among all the snail taxa, as indicated by the frequent occurrence of Pupilla triplicata $(\mathrm{n}=80)$, the absence/low frequency of hygrophilous species such as Clausilia dubia, Trochulus hispidus, Cochlicopa lubrica (O. F. Müller, 1774), and Pseudotrichia rubiginosa (Rossmässler, 1838), and the relatively low number of species.

The layer A2-3 snail faunal assemblage $(n=264)$ is made up of thirteen species which indicate relatively humid environmental conditions, as signaled by the occurrence of hygrophilous species, such as Clausilia dubia and Cochlicopa lubrica. Vestia turgida (Rossmässler, 1836), which typically inhabits wet marshes and stream banks, was found most frequently in layer A2-3, although it was also found in one sample in layer B-1. A single shell of the hygrophilous Vitrea crystallina was found in layer A2-3, further emphasizing the wet climate. The absence of Columella columella and Pupilla loessica and the decreased number of Vallonia tenuilabris in layer A2-3 indicates that the layer's sedimentation occurred in a warmer climate than that of layers A2-1 and $\mathrm{B}-1$.

The ratios of mollusc species we observed largely match with the data of Vlačiky and colleagues (2013, table 7) in the cases of layers A2-1 and A2-2. The mollusc samples of Vlačiky and colleagues (2013) at $85 \mathrm{~cm}$ and $105 \mathrm{~cm}$ depth derived from the upper and the lower boundaries of their layer III (Vlačiky et al. 2013, fig. 4) that is equivalent to our layer A2-3. Therefore, our snail sample from layer A2-3 was situated between the $85 \mathrm{~cm}$ and the $105 \mathrm{~cm}$ samples of 2008. This stratigraphic difference might have resulted in finding a slightly higher number of Pupilla loessica $(\mathrm{n}=10)$ and Pupilla sterri $(\mathrm{n}=12)$ in the sample at $85 \mathrm{~cm}$ (Vlačiky et al. 2013, table 7), compared to the frequency of these species we found in layer A2-3 ( $\mathrm{n}=0$ and $\mathrm{n}=1$, respectively). The sample at $105 \mathrm{~cm}$ from 2008 contained fewer Pupilla loessica $(\mathrm{n}=2)$ and Pupilla sterri $(\mathrm{n}=7)$. These species indicate a colder climate than what we estimate for layer A2-3, and thus their presence suggests that the $85 \mathrm{~cm}$ and $105 \mathrm{~cm}$ samples of 2008 could have been related with the sediments laying above and below archaeological layer A2-3.

\section{Vertebrate animals}

Animal remains were discovered in layers A2-2, A2-3 and B1. Layers $\mathrm{A} 2-1$ and $\mathrm{B}-2$ did not contain animal remains.

In layer $\mathrm{A} 2-2$, single bones were found of mammoth (mainly vertebrae), wolf, and Arctic/red fox. Layer A2-3 contained the most abundant animal remains, including mammoth $(\mathrm{NISP}=29, \mathrm{MNI}=1)$, reindeer $(\mathrm{NISP}=41, \mathrm{MNI}=2)$, wolf $(\mathrm{NISP}=21, \mathrm{MNI}=1)$, Arctic/red fox $(\mathrm{NISP}=2, \mathrm{MNI}$ $=1$ ), and hare (NISP $=7, \mathrm{MNI}=1)$. Additionally, in this layer, single bones of unidentified birds and rodents were also noted. Layer B-1 is similar to layers A2-2 and A2-3 in containing remains of mammoth (NISP $=25, \mathrm{MNI}=2)$, reindeer $(\mathrm{NISP}=7, \mathrm{MNI}=1)$, wolf $(\mathrm{NISP}=13, \mathrm{MNI}=1)$, and Arctic/red fox $(\mathrm{NISP}=12, \mathrm{MNI}=1)$. In layers A2-3 and $\mathrm{B}-$ 1 , some skeletal elements of carnivores were preserved in anatomical order. Generally, material identified to species/genus are known from earlier studies of this site (Vlačiky et al. 2013). A new discovery is of rodents (Microtus agrestis, Microtus gregalis, and Microtus oeconomus) from layer A2-3. 


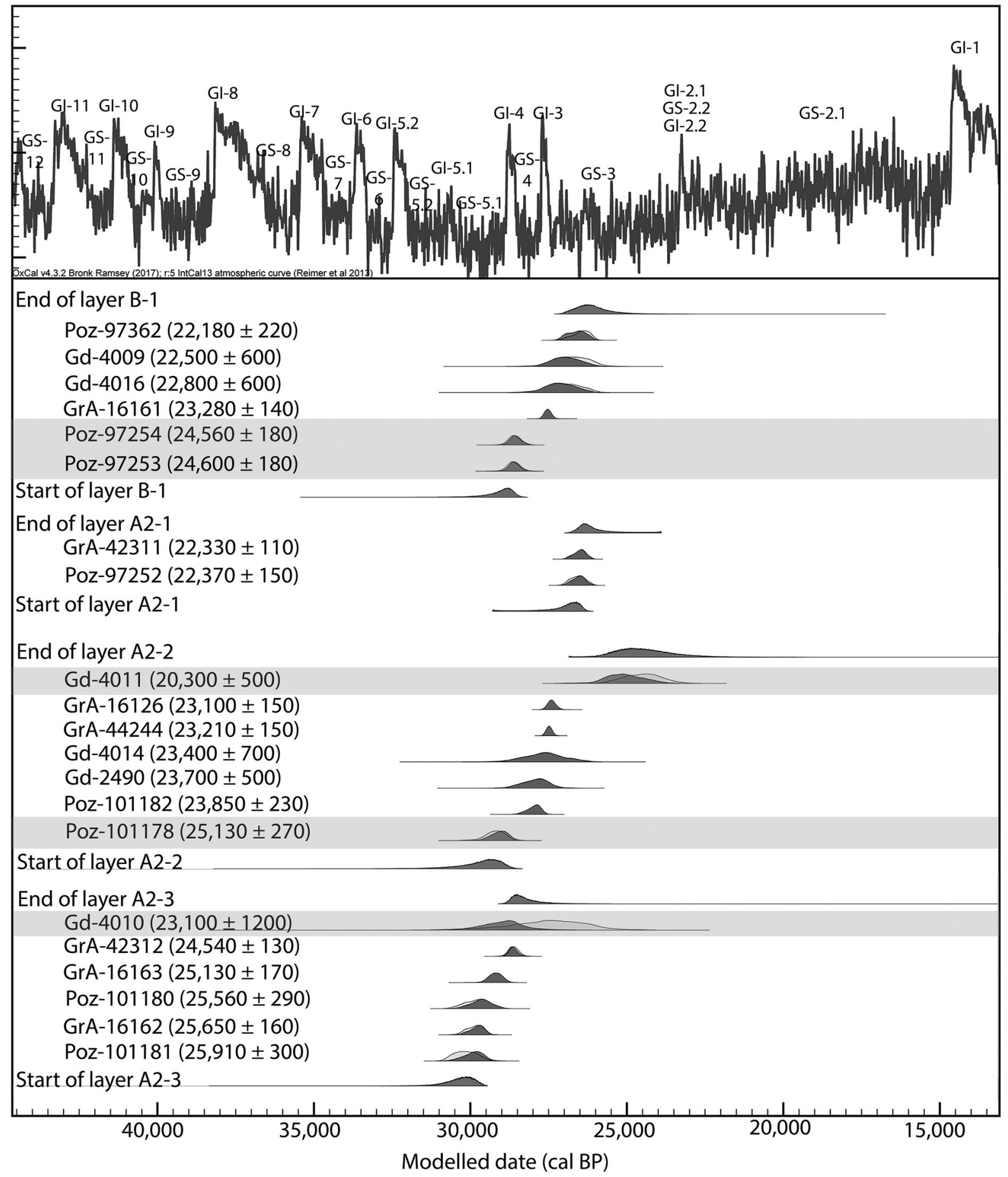

Figure 10. Modelled age of the human occupations using OxCal 4.3.2 (Reimer et al. 2013). Grey shades mark outlier dates.

Direct traces of human activity, such as cut- or punch marks, are few, which can be explained by the poor state of bone preservation. However, the context of their discovery -a human settlement discovered together with numerous artifacts and artificial structures-indicates that animal remains at the site are the results of human activity. The bones are heavily fragmented, which makes identification of element and taxon very difficult. The fragmentation was due to both post-depositional processes and, most likely, human activity. Bones were relatively often covered by root etching.

Our findings match the results of the fieldwork in 2008 (Vlačiky et al. 2013), except the case of layer A2-2 that contained mammoth bones, compared to the lack of this species in layer II of 2008.

\section{Knapped lithics}

The distribution of the raw materials used in the formal tool kits was different between the archaeological layers. What is especially important is that the proportions of the lithic raw materials in the tool assemblages accurately represent the complete collections.

Identified were five types of lithic raw materials in the formal toolkits of the layers. First is the erratic flint originating closest from glacial deposits of the Moravian gate (Prichystal 2013). This flint is of Cretaceous origin. Another type of flint is of Jurassic origin, which is found at the Kraków-Częstochowa Upland in Poland (Kaczanowska and Kozłowski 1976), but a coarser variant of this flint can be found in southern Moravia (Přichystal 2013). Polish Jurassic flint in 


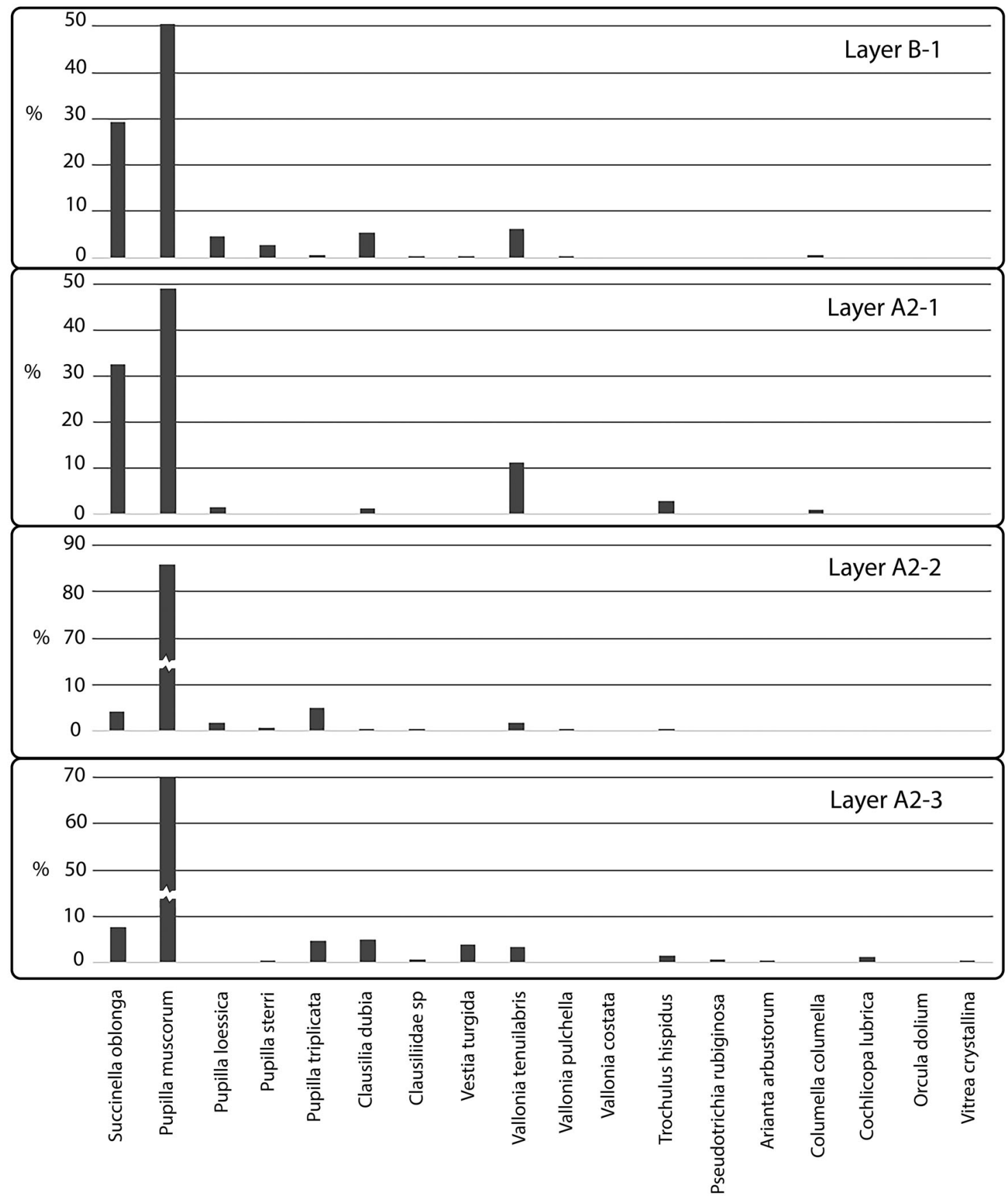

Figure 11. The distribution of mollusc fauna in the archaeological layers.

most cases has a brownish hue and finer texture. The Moravian type is predominantly of greyish hue. Locally available raw material at $\operatorname{TrB}$ was the radiolarite originating in the Klippen Belt of the White Carpathians (Prichystal 2013). The obsidian in the assemblages derived from the Tokaj Mountains of northeastern Hungary, type Carpathian 2 (Kasztovszky and Přichystal 2018). The fifth raw material category includes various siliceous rocks called limnic silicite. These were formed by post-volcanic activity of Miocene age in a lacustrine sedimentary environment (Přichystal 2013). The closest sources are in central Slovakia, but they might have originated from the volcanic ranges in northern Hungary, as well.

The layer A2-1 tool assemblage is made of radiolarite $(\mathrm{n}=$ $8)$, while formal tool assemblages from layers A2-2 $(n=122)$ and A2-3 $(n=848)$ have very similar proportions of raw materials, consisting of radiolarite, erratic flint, Jurassic flint, obsidian, and unidentified chert. In both assemblages, the erratic flint is dominant (54.9\% and 54.5\%); radiolarite is the next most abundant (35.2\% and $35.7 \%)$, while all the other materials make up less than $5.5 \%$. The sole, but slight, difference between them is the greater percentage of Jurassic flint in A2-3 (5.5\% versus $1.6 \%$ ). In layer B-1, radiolarite dominates $(88.5 \%)$, supplemented by erratic flint $(10.3 \%)$ and chert $(1.1 \%)$. Only one specimen of a radiolarite retouched tool was found in layer B-2.

Layer A2-1 has no lithic armatures and is dominated by domestic tools such as the edge retouched tools, end-scrapers, and burins (Figure 12, Table 4). Tools made on blades make up $62.5 \%$ of the assemblage, and tools made from flakes are in the minority. All edge retouched tools are blades, except the splintered tool made from a flake; the other types were made of both blades and flakes.

Layer A2-2 yielded a wider spectrum of tool types, including the armatures. The assemblage consists of mostly blade 

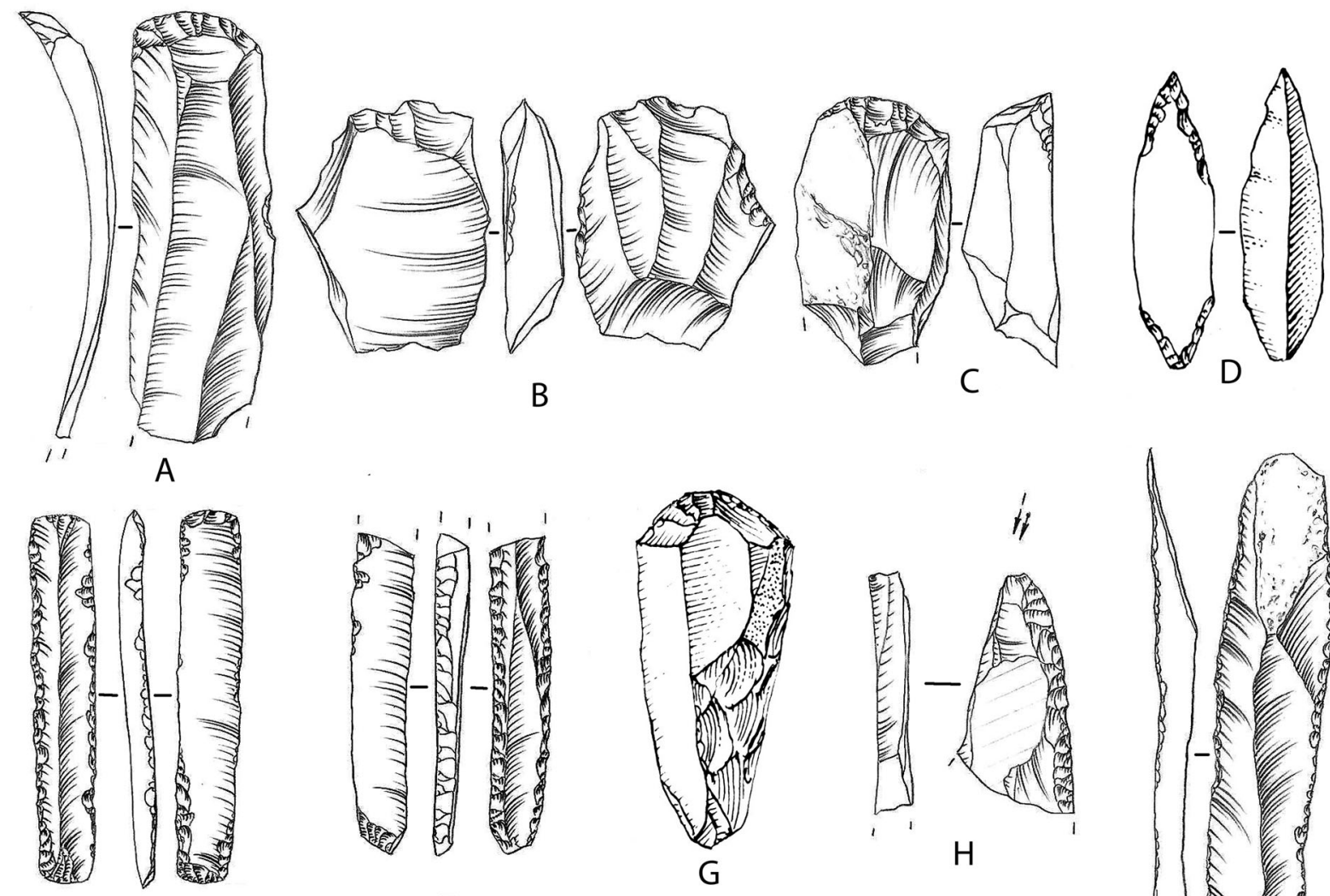

$\mathrm{E}$
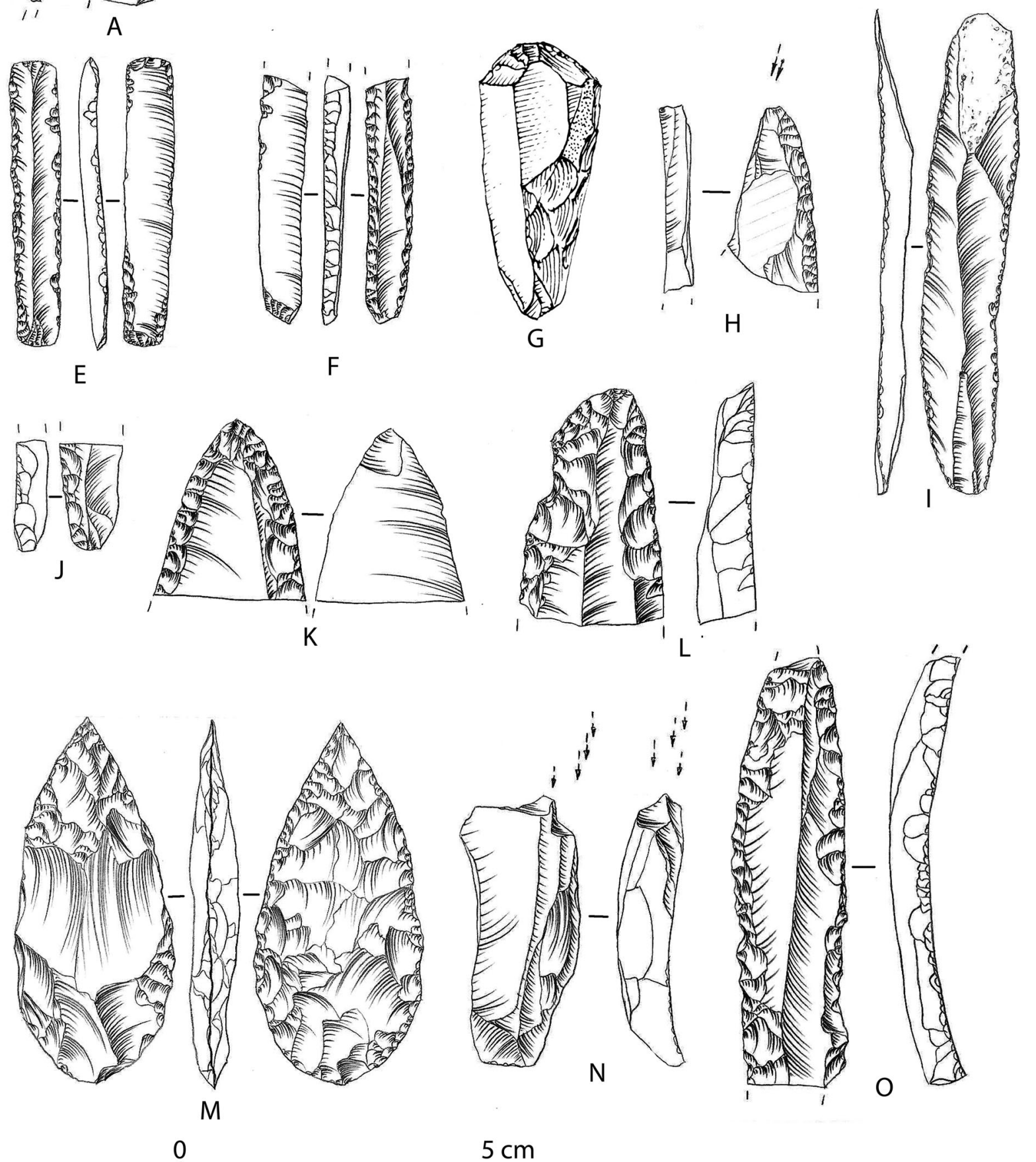

0

$5 \mathrm{~cm}$

Figure 12. Tools of layer A2-1 (A-C), layer A2-3 (D-J), and layer B-1 (K-O). A, C, G, L) end-scrapers; B) splintered tool; D) fléchette; E) backed and ventrally truncated bladelets (Late Gravettian rectangle); F) microgravette; $H, N$ ) burins; I, O) retouched blades; J) backed bladelet; K) retouched blade point; $M$ ) bifacial leaf point. (D and G are from Bárta 1988, figs. 3 and 2, respectively. All other artifacts were found in 2017, drawn by J Wilczyński).

tools (84.4\%). Edge retouched tools, burins, and end-scrapers dominate the domestic tool assemblage. The largest number of flake tools are burins $(n=10)$, and there are a few end- scrapers $(n=3)$ and edge retouched tools $(n=5)$; a single borer is made from a flake. The armatures make up $23 \%$ of the tool assemblage. Within the armatures, backed bladelets 
Table 4. Trenčianske Bohuslavice retouched tool inventories of areas $A 2, B 1$, and $B 2$.

\begin{tabular}{|c|c|c|c|c|c|c|}
\hline & $A 2-1$ & $\mathrm{~A} 2-2$ & $A 2-3$ & B-1 & B-2 & Total \\
\hline \multicolumn{7}{|l|}{ Domestic tools } \\
\hline \multirow[t]{2}{*}{ End-scraper } & 2 & 12 & 85 & 7 & 0 & 106 \\
\hline & $25.0 \%$ & $9.8 \%$ & $10.0 \%$ & $8.0 \%$ & $0.0 \%$ & $9.9 \%$ \\
\hline \multirow[t]{2}{*}{ Burin } & 2 & 32 & 214 & 7 & 0 & 255 \\
\hline & $25.0 \%$ & $26.2 \%$ & $25.2 \%$ & $8.0 \%$ & $0.0 \%$ & $23.9 \%$ \\
\hline \multirow[t]{2}{*}{ Edge-retouched } & 3 & 41 & 304 & 44 & 1 & 393 \\
\hline & $37.5 \%$ & $33.6 \%$ & $35.8 \%$ & $50.6 \%$ & $100.0 \%$ & $36.9 \%$ \\
\hline \multirow[t]{2}{*}{ Splintered } & 1 & 3 & 33 & 1 & 0 & 38 \\
\hline & $12.5 \%$ & $2.5 \%$ & $3.9 \%$ & $1.1 \%$ & $0.0 \%$ & $3.6 \%$ \\
\hline \multirow[t]{2}{*}{ Perforator/borer } & 0 & 1 & 7 & 0 & 0 & 8 \\
\hline & $0.0 \%$ & $0.8 \%$ & $0.8 \%$ & $0.0 \%$ & $0.0 \%$ & $0.8 \%$ \\
\hline \multirow[t]{2}{*}{ Truncated } & 0 & 3 & 18 & 5 & 0 & 26 \\
\hline & $0.0 \%$ & $2.5 \%$ & $2.1 \%$ & $5.7 \%$ & $0.0 \%$ & $2.4 \%$ \\
\hline \multirow[t]{2}{*}{ Combined } & 0 & 2 & 13 & 0 & 0 & 15 \\
\hline & $0.0 \%$ & $1.6 \%$ & $1.5 \%$ & $0.0 \%$ & $0.0 \%$ & $1.4 \%$ \\
\hline \multirow[t]{2}{*}{ Knife } & 0 & 0 & 0 & 1 & 0 & 1 \\
\hline & $0.0 \%$ & $0.0 \%$ & $0.0 \%$ & $1.1 \%$ & $0.0 \%$ & $0.1 \%$ \\
\hline \multicolumn{7}{|l|}{ Armature } \\
\hline \multirow[t]{2}{*}{ Backed blade/let } & 0 & 14 & 50 & 0 & 0 & 64 \\
\hline & $0.0 \%$ & $11.5 \%$ & $5.9 \%$ & $0.0 \%$ & $0.0 \%$ & $6.0 \%$ \\
\hline \multirow[t]{2}{*}{ Backed-truncated blade/let } & 0 & 0 & 1 & 0 & 0 & 1 \\
\hline & $0.0 \%$ & $0.0 \%$ & $0.1 \%$ & $0.0 \%$ & $0.0 \%$ & $0.1 \%$ \\
\hline \multirow[t]{2}{*}{ Rectangle } & 0 & 0 & 3 & 0 & 0 & 3 \\
\hline & $0.0 \%$ & $0.0 \%$ & $0.4 \%$ & $0.0 \%$ & $0.0 \%$ & $0.3 \%$ \\
\hline \multirow[t]{2}{*}{ LG rectangle } & 0 & 5 & 67 & 1 & 0 & 73 \\
\hline & $0.0 \%$ & $4.1 \%$ & $7.9 \%$ & $1.1 \%$ & $0.0 \%$ & $6.8 \%$ \\
\hline \multirow[t]{2}{*}{ Gravette/microgravette } & 0 & 0 & 16 & 0 & 0 & 16 \\
\hline & $0.0 \%$ & $0.0 \%$ & $1.9 \%$ & $0.0 \%$ & $0.0 \%$ & $1.5 \%$ \\
\hline \multirow[t]{2}{*}{ Retouched blade point } & 0 & 8 & 30 & 3 & 0 & 41 \\
\hline & $0.0 \%$ & $6.6 \%$ & $3.5 \%$ & $3.4 \%$ & $0.0 \%$ & $3.8 \%$ \\
\hline \multirow[t]{2}{*}{ Fléchette } & 0 & 1 & 3 & 0 & 0 & 4 \\
\hline & $0.0 \%$ & $0.8 \%$ & $0.4 \%$ & $0.0 \%$ & $0.0 \%$ & $0.4 \%$ \\
\hline \multirow[t]{2}{*}{ Vachons point } & 0 & 0 & 3 & 0 & 0 & 3 \\
\hline & $0.0 \%$ & $0.0 \%$ & $0.4 \%$ & $0.0 \%$ & $0.0 \%$ & $0.3 \%$ \\
\hline \multirow[t]{2}{*}{ Bifacial leaf point } & 0 & 0 & 1 & 18 & 0 & 19 \\
\hline & $0.0 \%$ & $0.0 \%$ & $0.1 \%$ & $20.7 \%$ & $0.0 \%$ & $1.8 \%$ \\
\hline \multirow[t]{2}{*}{ Total } & 8 & 122 & 848 & 87 & 1 & 1066 \\
\hline & $100.0 \%$ & $100.0 \%$ & $100.0 \%$ & $100.0 \%$ & $100.0 \%$ & $100.0 \%$ \\
\hline
\end{tabular}

and retouched blade points are the most numerous. The layer A2-3 tool assemblage is also strongly dominated by blade tools $(92.1 \%)$. Flake tools are most often burins $(n=27)$, splintered tools $(n=18)$, edge retouched tools $(n=10)$, or end-scrapers $(n=5)$. The domestic tool spectrum is almost identical to what is found in the layer A2-2 assemblage. The armatures make up 20.5\%, within which the Gravette/ microgravette group, absent in layer A2-2, is represented several times.

The 2008 lithic tool collection's (Vlačiky et al. 2013) typological spectrum correlates with our results from area A2 concerning all the three layers.

The layer B-1 tool kit is also dominated by blades (63.2\%), and most of the flakes are edge-retouched tools $(n=9)$. The blanks of the BLPs are classified as unknown, because the retouching removed all diagnostic features needed to identify blank types. There are two BLPs on which unretouched removal scar surfaces were preserved: thus we suppose the blanks of the unknown BLPs were also flakes. Armatures make up $25.3 \%$ of the assemblage, with BLPs being dominant. The single tool of layer B-2 is a retouched flake.

\section{Use-wear analysis}

We studied 192 artifacts, including retouched tools $(n=71)$, unretouched blades $(\mathrm{n}=96)$, and bifacial thinning flakes $(n=25)$. Use-wear traces appeared on a significant portion of the studied assemblage $(30 \%, \mathrm{n}=56)$. Items showing no use-wear $(n=136)$ are mainly blank blades $(n=85)$, all the bifacial thinning flakes, and a small portion of the retouched tools $(n=26)$.
Layers A2-1 and A2-2 yielded a small number of tools with traces of use. This includes two burins of layer A2-1, which preserved use scars on their burin tips, and a mesial fragment of a retouched blade of layer A2-2, used for sawing bone/antler.

Layer A2-3 produced tools used for various domestic activities. Retouched $(\mathrm{n}=3)$ and unretouched blades $(\mathrm{n}=1)$ were used for cutting soft animal tissue and scraping hides. Retouched blades, a burin, and an end-scraper were used for processing bone/antler. The retouched blades $(n=4)$ were used for sawing and scraping $(n=1)$, while the burin was used to carve bone/antler, and the end-scraper was a tool for adzing. A possible ochre stain was detected on the passive part of the end-scraper. One of the other retouched blades was probably used for whittling wood. A further 23 tools were used in undetermined activities. Most of them are incomplete specimens, nevertheless there are four retouched blades and an end-scraper bearing hafting polish. Hunting activity is not reflected in traces of use, excluding one retouched blade with an impact scar.

In layer B-1, a hunting practice was noticed through the presence of two artifacts with impact traces. One artifact is a retouched pointed blade that bears the impact scar on its tip's ventral face (Figure $12 \mathrm{~K}$ ). The other tool is a BLP (Figure 13) with bifacial step and hinged bending fractures at its tip (Figure 13A). The lateral edges near the BLP's tip are partially rounded and polished, and the polished area is cut through by short and narrow striations, parallel to the cutting edge (Figure 13B). A bright haft polish also was noticed on the ridges bordering the flake scars in the middle part of one of the surfaces of the BLP (Figure 
Table 5. Lithic artifacts use-wear analyses results.

\begin{tabular}{|c|c|c|c|c|c|c|c|}
\hline Layer & Type & Impact traces & Soft material & Hard material & Undetermined material, other & No traces & Total \\
\hline \multirow[t]{5}{*}{$\overline{A 2-1}$} & End-scraper & - & - & - & - & 1 & $\overline{1}$ \\
\hline & Burin & - & - & - & 2 & - & 2 \\
\hline & Edge-retouched & - & - & - & - & 1 & 1 \\
\hline & Blade & - & - & - & - & 12 & 12 \\
\hline & Sub-total & - & - & - & 2 & 14 & 16 \\
\hline \multirow[t]{3}{*}{$A 2-2$} & Edge-retouched & - & - & 1 & - & - & 1 \\
\hline & Blade & - & - & - & - & 1 & 1 \\
\hline & Sub-total & - & - & 1 & - & 1 & 2 \\
\hline \multirow[t]{12}{*}{$A 2-3$} & End-scraper & - & - & 1 & 1 & 1 & 3 \\
\hline & Burin & - & - & 1 & 2 & 1 & 4 \\
\hline & Edge-retouched & 1 & 3 & 6 & 8 & 6 & 24 \\
\hline & Splintered & - & - & - & 2 & 4 & 6 \\
\hline & Borer & - & - & - & - & 1 & 1 \\
\hline & Truncated & - & - & - & - & 1 & 1 \\
\hline & Backed & - & - & - & 2 & 2 & 4 \\
\hline & LG rectangle & - & - & - & 2 & 1 & 3 \\
\hline & Gravette/Microgravette & - & - & - & - & 1 & 1 \\
\hline & Retouched point & - & - & - & 1 & - & 1 \\
\hline & Blade & - & 1 & - & 5 & 36 & 42 \\
\hline & Sub-total & 1 & 4 & 8 & 23 & 54 & 90 \\
\hline \multirow[t]{10}{*}{ B-1 } & End-scraper & - & - & - & 1 & 1 & 2 \\
\hline & Burin & - & 1 & - & - & - & 1 \\
\hline & Edge-retouched & 1 & - & - & 4 & 2 & 7 \\
\hline & Splintered & - & - & - & - & 1 & 1 \\
\hline & Truncated & - & 2 & - & - & 1 & 3 \\
\hline & Retouched point & - & - & - & 1 & & 1 \\
\hline & Bifacial leaf point & 1 & 1 & - & - & 1 & 3 \\
\hline & Blade & - & - & 2 & 3 & 36 & 41 \\
\hline & Bifacial thinning flake & - & - & - & - & 25 & 25 \\
\hline & Sub-total & 2 & 4 & 2 & 9 & 67 & 84 \\
\hline Total & & 3 & 8 & 11 & 34 & 136 & 192 \\
\hline
\end{tabular}

13C). Further traces of working on soft animal tissue, hides, and meat were recorded on truncated pieces $(n=2)$ (Figure $14 \mathrm{~A})$, a burin $(\mathrm{n}=1)$, and a bifacial knife $(\mathrm{n}=1)$ (Figure $14 \mathrm{~B})$. The truncated blade and the bifacial knife (Figure 14) were used for cutting. The right lateral edge of the knife remained roughly shaped, and the opposite edge was retouched to a sharp tip. The left edge adjoining the tip is rounded and covered by greasy polish, and tiny scratches parallel to the edge are visible (Figure 14B). Blank blades $(n=2)$ were used for sawing bone/antler. The determination of the use failed for nine artifacts. Blades $(n=3)$ and retouched flakes $(n=2)$ having a weak polish indicate a short usage time. Retouched blades $(n=2)$, an end-scraper, and a retouched point bear intense traces of wear and hafting, which suggest storage and reutilization of the same tool. The lack of use-wear traces on the bifacial thinning flakes (n $=25$ ) proves no re-sharpening of used bifacial tools at the site.

\section{Adornments}

Bárta (1988) reported pendants made of flat limestone pebbles, without specifying their manufacturing technology and the number of finds. All pebble pendants were found in area $\mathrm{B}$ in association with the BLP lithic industry (layer B-1).

The collection consists of 14 modified pebbles, of which 13 are drilled and one shows the mark of drilling, although a penetrating hole was not achieved (Figure 15A). Except for one, all the drilled specimens were made of white quartzite pebbles. The exception is a greyish-brown sandstone pebble. A total of eight specimens of the drilled pebbles are complete, and five are broken. The breakage always occurred at the eye of the pendant. The pendant eye was made in each case by perforating both faces of the pebble. The eyes are therefore biconical in section. The outline of the quartzite pebbles are naturally tear-drop or oval, while the one sandstone item is circular in shape. The original outline of the pebble always remained intact.

Two items were further decorated with paired parallel incised lines on the edges of the pebbles (Figure 15A: 1-2). One pendant has five pairs of lines on one edge and six pairs of lines on the other edge (Figure 15B: 1). The second incised pebble has three pairs of lines (Figure 15B: 2).

By length, the pendants can be divided into two groups: greater than $35 \mathrm{~mm}$ and shorter than $25 \mathrm{~mm}$. By thickness, most items are thinner than $8 \mathrm{~mm}$. By width, most are narrower than $25 \mathrm{~mm}$. The sandstone item is always an outlier. The incised items belong to the larger kind of pendant. Most broken items and the unfinished specimen belong to the smaller kind. It is unclear whether the broken items were damaged during production or while in use.

Apart from the pierced pendants, blanks for making pendants were also found solely in area B. A total of 42 small, flat pebbles were found by Bárta in the 1980s, and 41 items were found in 2017. The majority of these pebbles are quartzite ( $n$ $=71$ ), two pebbles are fossils, one is granite, and the rest are limestone or sandstone. The origin of the pebbles is still unclear, since Bošáčka gravel is entirely composed of limestone pebbles, and the Váh valley gravel contains mostly limestone and sandstone pebbles, rarely radiolarite pebbles, and hardly any quartzite.

The only personal ornament of layer A2-3 in area A2 is a pierced canine tooth from a red deer (Cervus elaphus) recovered in the 1980s but which remained unpublished (Figure 15C). The eye of the pendant is broken and was made at the root of the tooth by perforating from opposites faces, similarly to the drilling of the pebble pendants in area B. Therefore, the shape of the hole is also biconical, and the pendant's shape again resembles a tear-drop. 

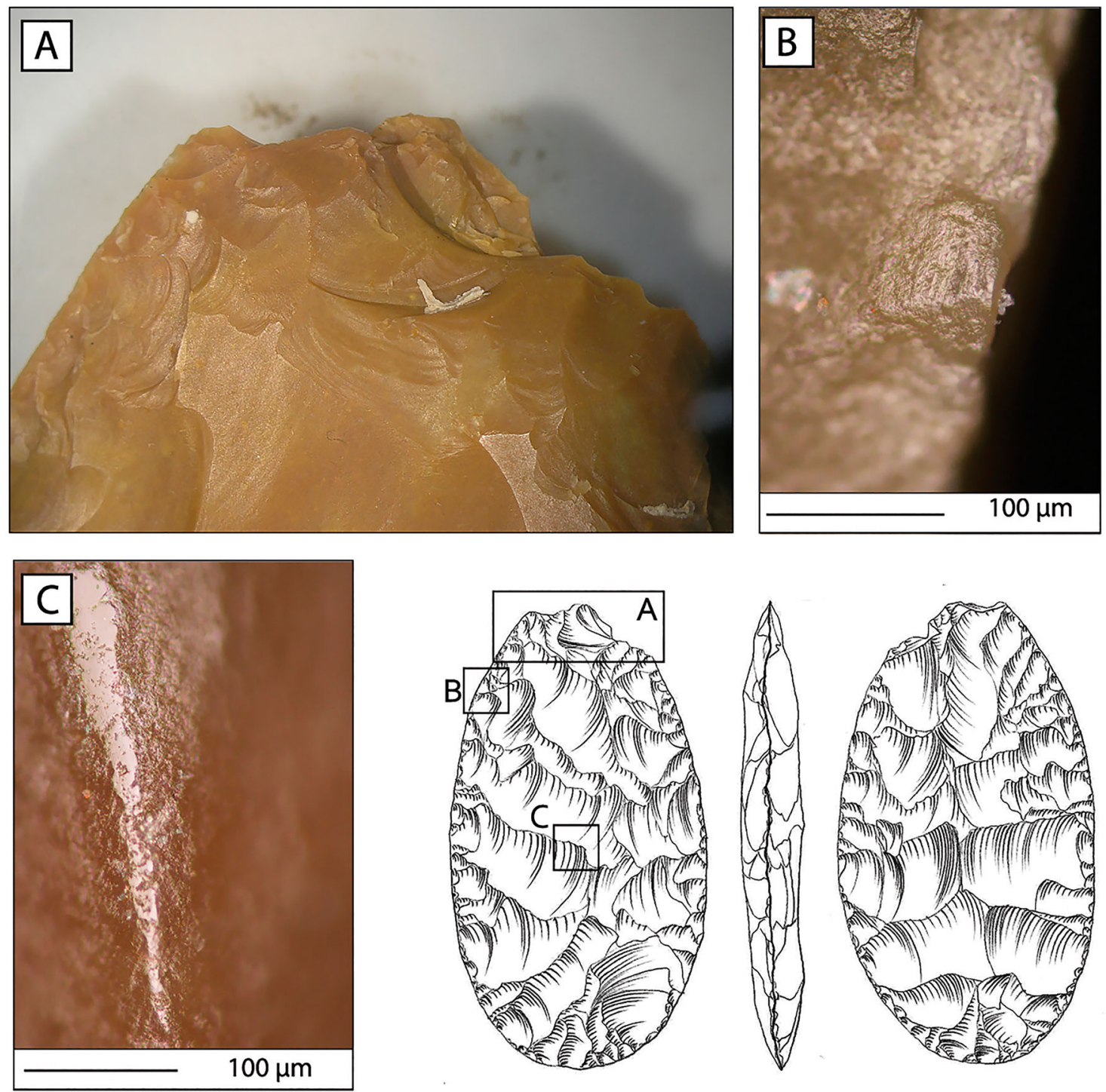

0

$3 \mathrm{~cm}$

Figure 13. A bifacial leaf point from excavation area B, layer B-1, with impact fracture (A), use-wear on the edge (B), and hafting polish on the surface (C).

\section{Discussion and Conclusions}

The most awaited question to answer in regard to the archaeological record of $\operatorname{TrB}$ human occupation is the stratigraphic correlation between areas A and B. Former attempts (Verpoorte 2002; Vlačiky et al. 2013) were unsuccessful in accomplishing this task, mainly due to the fact that stratigraphic depth data of the 1980s was insufficient to reconstruct the order of the radiocarbon samples because of the steep slope of the Pod Tureckom area behind the Turecký Vrch. This situation was responsible for covering the archaeological layers with significantly varying thicknesses of sediments between areas A2 and B. Therefore, the method of Verpoorte (2002) that sorted the radiocarbon dates and the archaeological layers according to depth data resulted in a mixed order of the human occupation. Another issue that caused inaccuracy in the chronology of the site arose from Bárta's layer numbering. Verpoorte (2002) and Vlačiky and colleagues (2013) provided layer numbers for the dates of the 1980s arranged ascending from top to bottom. However, the archives of the 1980s excavations and the Gliwice Radiocarbon Laboratory include a radiocarbon date submission sheet on which Bárta numbered the layers descending from bottom to top (Figure 3A).
As best we can establish, the earliest human occupation at $\operatorname{TrB}$ is found in layer B-2, dated to 38.3-35.8 kya. This period is largely coeval with the GI-8 interstadial (Rasmussen et al. 2014), which explains the soil formation found related with layer B-2. This layer can be correlated with the lowest archaeological layer that Bárta found in an Interpleniglacial soil in area A1. Besides the same stratigraphic position, the low number of artifacts and the lack of Gravettian character also coincide with the features presented by Bárta (1988) for the lowest layer. The thin list of tool types does not allow specification of the cultural affiliation of this lithic industry. In western Slovakia, Dzeravá skála Cave occupation yielded Aurignacian osseous points dated to 38.3-33.2 kya (Davies and Hedges 2005); in Moravia, modern human teeth at Mladeč Cave date to 36.2-34.3 kya (Wild et al. 2005); and, at Stránská Skála, Aurignacian dates fall between 38.7 and 31.8 kya (Svoboda 2003). Based on the chronological overlap of these sites, we suspect that layer B-2 belongs to the Aurignacian occupation of the western Carpathians.

The next occupation is in layer A2-3. This layer yielded the densest archaeological remains, being the main Gravettian occupation by the definition of Bárta (1988). The lithic toolkit contains all the armatures of the Late Gravettian of central Europe (Lengyel 2016, 2018; Lengyel and Wilczyński 

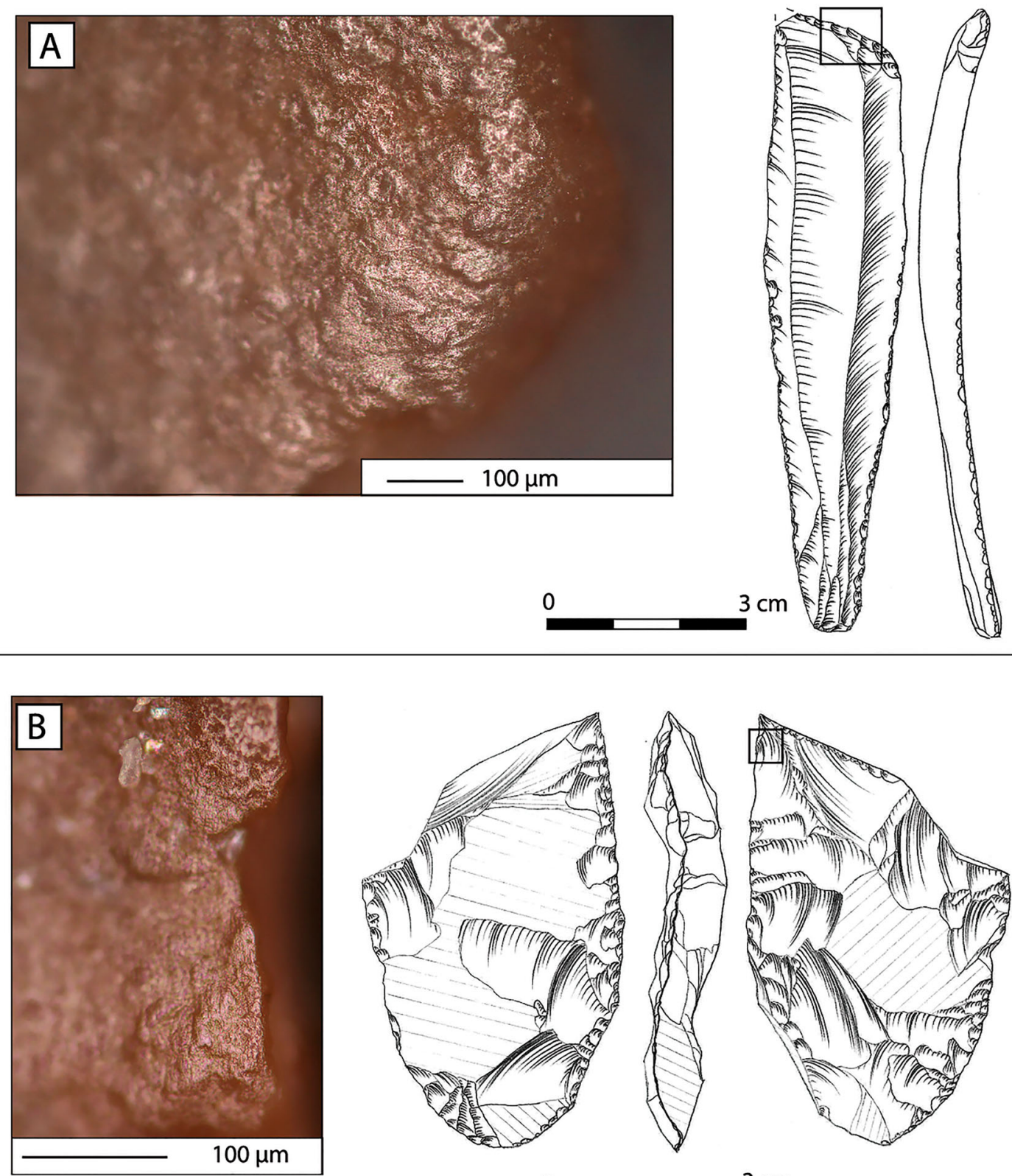

$3 \mathrm{~cm}$

Figure 14. Use-wear traces on a truncated blade (A) and a bifacial knife (B) of excavation area B, layer B-1.

2018). The age 30.5-29.0 kya also falls into the span of the Late Gravettian chronology (Lengyel and Wilczyński 2018; Wilczyński et al. 2020) and correlates with the GS-5.1 stadial phase (Rasmussen et al. 2014). Besides the radiocarbon ages, the geological data showed this layer was embedded within a windblown sediment, partially redeposited in slope position, which is typical for stadial events. The sole artistic object is a pendant made of a deer canine tooth. This raw material is absent in the Pavlovian of southern Moravia, where personal ornaments were most often made of fox and wolf incisors and canines (Lázničková-Galetová 2011; Wojtal et al. 2012, 2018), and rarely from reindeer teeth (Wojtal et al. 2012). A single exemplar of a pendant made of red deer canine was found at Lubná II Late Gravettian site, of a similar age, which is decorated by incisions (Šída et al. 2015, figs. 154, 155).

Superposing layer A2-3, layer A2-2 also belongs to the Late Gravettian occupation of the area on the basis of the backed bladelets, the rectangle of Late Gravettian type, the fléchette, and the Vachons point (Lengyel 2015, 2016, 2018; Wilczyński 2016). The sole difference between A2-3 and
A2-2 is the lack of Gravette/microgravette points in A2-2. The calibrated radiocarbon age 29.0-27.1 kya falls into the chronological position of this type of lithic industry of central Europe (Lengyel and Wilczyński 2018; Wilczyński et al. 2020), which is coeval mostly with the GS-4 stadial and overlaps GI-4, GI-3, and GS-3 (Rasmussen et al. 2014).

On the basis of the radiocarbon measurements, the next human occupation is the BLP assemblage of area B in layer B-1, dated to between 27.7 and 25.9 kya. The period between 27.7 and 25.9 kya corresponds with the GS-3 stadial leading to the Last Glacial Maximum (Rasmussen et al. 2014). The mollusc faunal spectra support the radiometric age correlation and showed identity between layers B-1 and A2-1. The molluscan fauna of layers B-1 and A2-1 include species with cold preferences, indicating the coldest period in the stratigraphic sequence at $\operatorname{TrB}$, which corresponds with the development of the LGM in the region. Also, the gley soil formation in layer B-1, which is the only periglacial phenomenon in the strata, further supports the estimated early LGM chronological position of layer B-1. 


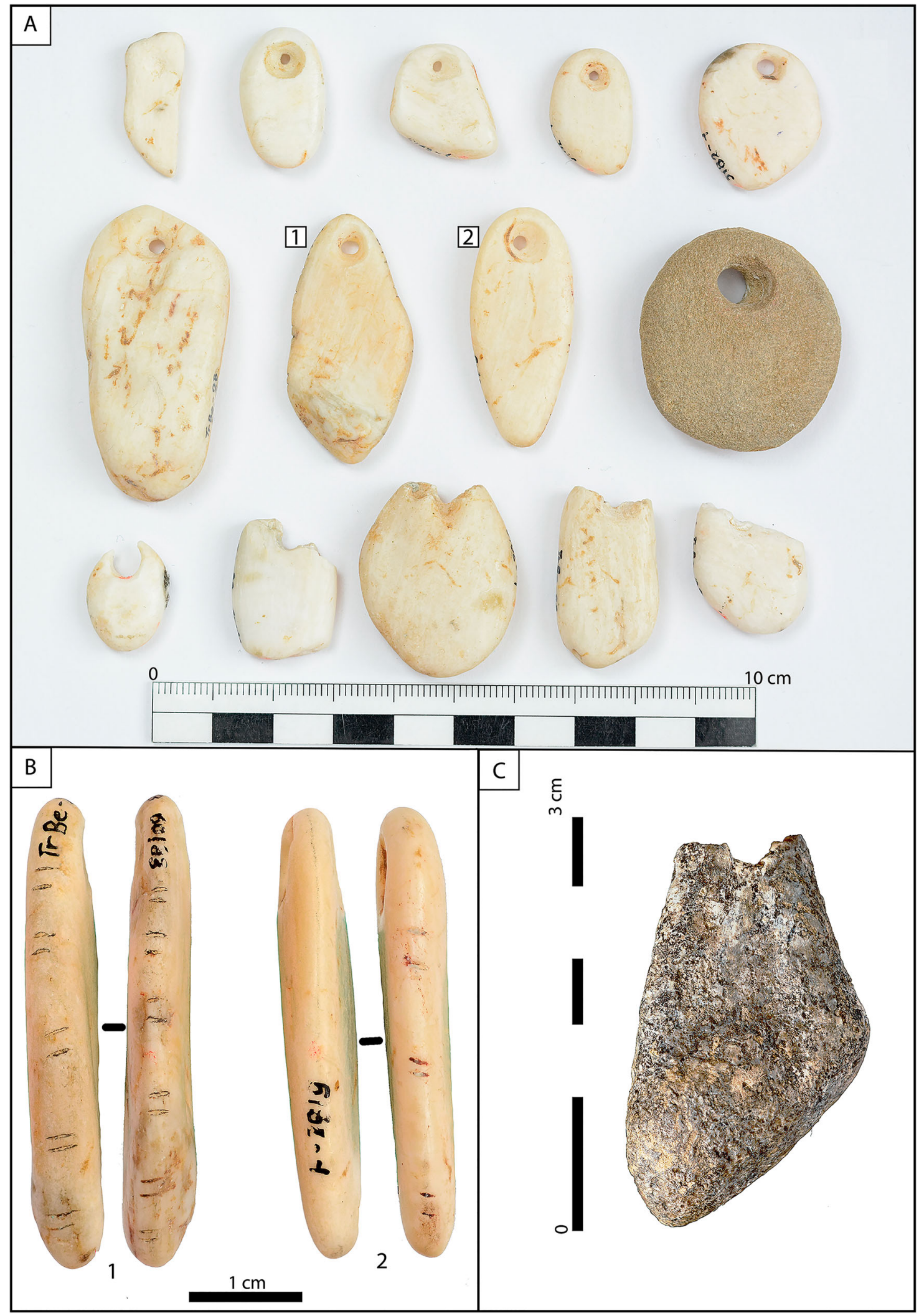

Figure 15. A) Pierced pebble pendants of layer B-1; B) two of which have incisions on their edges; and, C) the tooth pendant of layer A2-3.

However, the results of charcoal analysis support this only partially.

The charcoal remains mainly derived from the human gathering of firewood, and it is likely that all available wood was chosen for fuel. In the Weichselian glacial conditions of central Europe, Pinus and Picea or Larix are the most frequent taxa of trees found in the charcoal assemblages from archaeological sites before and during the LGM (Willis and van Andel 2004). The stratigraphic record at $\operatorname{TrB}$ shows a change in the distribution of tree species in area A2 from the bottom to the top. The widest spectrum of trees was found in layers A2-3 and B-1, in similar proportions. Layer A2-2 yielded only Picea or Larix, and layer A2-1 is the only one to include Pinus sylvestris-mugo. This distribution shows that during occupations A2-3 and B-1, a possibly similar vegetal environment characterized the Váh valley. There is a dominance of Picea or Larix charcoal in layers A2-2 and B-2, but it is also probable that the unspecified 
coniferous charcoal fragments belong to Pinus. However, we suspect that a change in charcoal assemblages from Picea or Larix-dominated layers in A2-3, A2-2, and B-1 to the presence of Pinus sylvestris-mugo in A2-1 might be significant in the vegetation at the beginning of the LGM. Based on recent ecological conditions, both trees Picea or Larix, most likely Picea abies and Larix decidua in central European sites, can be regarded as growing on semi-permanently frozen soils, although Larix decidua is better adapted to colder conditions and nowadays grows in the mountains, together with Pinus cembra above Picea abies-dominated forests. Pinus cembra and Pinus sylvestris, together with $P$. mugo, can also grow under conditions of a full-glacial environment (Willis, Rudner, and Sümegi 2000). The slight decrease in coniferous wood charcoal abundance in layer A2-1 may also indicate a cooling climate. Out of the 18 snail species identified, four have woodland preferences and another four prefer intermediate environments between open habitat and woodland. Except the $89.1 \%$ in layer A2-3, the proportion of snails preferring open habitat makes up $94.4-99.8 \%$ of all species in each layer. Thus, compared to layers A2-2, B-1, and A2-1, during the formation of layer A2-3, a slightly more expanded forest cover can be reconstructed, similarly to what has been recovered from Pavlovian sites dated to 31 kya in nearby Moravia (Beresford-Jones et al. 2010; Cichocki, Knibbe, and Tillich 2014; Svoboda et al. 2015), while the coniferous trees may have formed only patches of trees near the site at the onset of the LGM. These results indicate that LGM environmental conditions might have been fully formed already during the formation of layer A2-1 in the Váh valley.

The archaeological, radiometric, paleobotanical, stratigraphic, and snail faunal evidence straightforwardly generates an argument for the cultural classification of layer B-1 in the UP in ECE. BLP-maker hunter-gatherers were primarily associated with the Middle to Upper Palaeolithic transitional period, the EUP (Škrdla et al. 2014), and the Late Gravettian (Simán 1990; Lengyel, Mester, and Szolyák 2016), but never occurred postdating the Late Gravettian. The dating results argue against a MP-UP transitional Szeletian occupation at the $\operatorname{TrB}$ site; this phase is dated to $37-44$ kya in the region (Kaminská, Kozłowski, and Škrdla 2011; Škrdla et al. 2014; Hauck et al. 2016). The lack of Gravettian armatures in $\operatorname{TrB}$ Layer B-1 does not allow identifying this assemblage as Late Gravettian with bifacial leaf points, because each Late Gravettian assemblage with leaf points has at least three further types of the Gravettian armature, besides the bifacial tools and the retouched points (Novák 2008; Lengyel, Mester, and Szolyák 2016), which are missing in the layer B-1 assemblage. The lack of diagnostic Gravettian tool types in the latest human occupations at $\operatorname{TrB}$ actually corresponds with the gradual disappearance of Gravettian type armatures in the archaeological record of ECE during the transition from the Late Gravettian to the Epigravettian as the LGM developed to its apex (Lengyel 2016, 2018; Lengyel and Wilczyński 2018). The pendants made of small pebbles in layer B-1 occasionally appear in both the Late Gravettian (Kazior, Kozłowski, and Sobczyk 1998, fig. 36) and Early Epigravettian assemblages (Montet-White 1990, fig. IX-14). The layer B-1 lithic assemblage also presents a shift in the raw material economy compared to layers A2-3 and A2-2, having been made mostly from the local radiolarite. This fits a general tendency found in the archaeological record of the Carpathian Basin, in which the lithic raw material procurement strategy changes from distant to local as the Late Gravettian fades out and the Early Epigravettian emerges at the onset of the LGM (Svoboda and Novák 2004; Kozłowski 2013; Lengyel 2014, 2018). Therefore, the chronological position of layer B-1's BLP industry is unique in ECE. A similar archaeological record is found in western Europe, where the formation of the BLP-producing Middle Solutrean was linked with the global cooling by the LGM (Banks et al. 2009; Renard 2011). Currently, it is unwise to interpret the TrB BLP assemblage as Solutrean. Most likely, we need to regard the BLP as a tool type that emerged in the Late Middle Palaeolithic in Neanderthal technology (Richter 2016) but kept recurring with uneven frequency throughout the Bohunician (Škrdla 2017), Jankovichian (Mester 2017), Szeletian (Mester 2018), Aurignacian (Oliva 1990), and Gravettian (Lengyel, Mester, and Szolyák 2016) up to the LGM, and it is not a distinctive archaeological index fossil.

In the sequence of human occupation at $\operatorname{TrB}$, it is only layer A2-1 that fully represents Early Epigravettian features of ECE (Lengyel 2018) by lacking any piece of distant lithic raw material and Gravettian armature. The dating of layer A2-1 places the occurrence of the Early Epigravettian type lithic industry to ca. $26.0 \mathrm{kya}$, which is two millennia earlier than expected. The occurrence of the Epigravettian was generally found to have been coeval with the onset of the LGM (Lengyel and Wilczyński 2018), based on chronologies that roughly date this event to 25-23 kya (Hughes and Gibbard 2015; Hughes et al. 2016; Stroeven et al. 2016; Patton et al. 2017). The archaeological results of the research at $\operatorname{TrB}$, however, provide the first radiocarbon ages of the Epigravettian, fitting the onset of the LGM defined by Clark and colleagues (2009), which showed that the terrestrial ice sheets reached their maximum extent by $26.5 \mathrm{kya}$ at the earliest on a global scale, based on the Greenland ice core GS-3 stadial record (Hughes and Gibbard 2015). Therefore, there is a chance that archaeological records linked with the onset of the LGM in ECE might produce earlier radiometric ages than usually expected.

\section{Acknowledgments}

J. W. was supported by the National Science Centre (NCN), Poland, decision No: UMO-2015/18/E/HS3/00178. A. N. was also supported by the research project APVV-14-0742, Dynamics of the exploitation of silicate material resources during the Palaeolithic and Neolithic in the western Slovakia. B. P. G was supported by the Premium Postdoctoral Research Grant of the Hungarian Academy of Sciences (MTA). G. L. was supported by the National Science Centre (NCN), Poland, decision No. DEC-2016/23/P/HS3/04034, the ÚNKP-19-4P New National Excellence Program of the Ministry for Innovation and Technology (TNRT/1419/51/2019), and the Bolyai János Research Fellowship (BO/00629/19/2) of the Hungarian Academy of Sciences (MTA). This project has received funding from the European Union's Horizon 2020 research and innovation program under the Marie SkłodowskaCurie grant agreement No. 665778. M. MdH. was partly supported by the stautory research of IB PAS. We are grateful to Michal Horsák (Masaryk University, Czech Republic) for identifying some of the helicoid shells and Prof. Natalia Piotrowska of the Department of Radioisotopes at the GADAM Centre, Gliwice, Poland, for providing access to the archives of the Gliwice Radiocarbon Laboratory.

\section{Disclosure Statement}

No potential conflict of interest was reported by the author(s). 


\section{Notes on Contributors}

Jarosław Wilczyński (Ph.D. 2010, Institute of Systematics and Evolution of Animals, PAS, Kraków, Poland) is an archaeologist and archaeozoologist. His archaeological research focuses on the Upper Palaeolithic of central Europe, especially on the Gravettian and the Epigravettian cultures, studying lithic raw material distribution, lithic tool technology, and lithic tool typology. His archaeozoological research involves mammalian remains from both Pleistocene and Holocene prehistoric periods.

Ondrej Žaár (Ph.D. 2013, Constantine the Philosopher University, Nitra, Slovakia) is a head researcher of PAMARCH, Ltd. company in Nitra, Slovakia, which deals with the protection, revitalization, and reconstruction of monuments, as well as corresponding research in archaeology and historical architecture. He specializes on Palaeolithic research along the rivers Váh and Nitra, the Morava valleys, and central Europe, with an emphasis on field prospection and spatial analysis of archaeological site distribution.

Adrián Nemergut (Ph.D. 2012, Masaryk University, Brno, Czech Republic) is an archaeologist in the Palaeolithic and Mesolithic periods, with a focus on the technology of lithic industries and raw material procurement. From 2015-2019, he was a postdoctoral researcher at the Institute of Archaeology, Slovak Academy of Sciences, where he currently holds a position as a scientific researcher at the Department of the Prehistoric Archaeology.

Bernadeta Kufel-Diakowska (Ph.D. 2008, University of Wrocław, Poland) is an assistant professor at the Laboratory of Archaeometry and Archaeological Conservation of the Institute of Archaeology of the University of Wroclaw. She studies subsistence economy and the lifestyle of hunter-gatherers and early farmers. She specializes in use-wear analysis of lithic tools and experimental archaeology. She is engaged in research projects concerning human activities in the Upper and Late Palaeolithic and the Neolithic period.

Magdalena Moskal-del Hoyo (Ph.D. 2010, University of Valencia, Spain) is a researcher at the Department of Palaeobotany of the W. Szafer Institute of Botany of the Polish Academy of Sciences. Her main scientific interests include the reconstructions of past woodland vegetation from charcoal and wood remains of Pleistocene and Holocene archaeological and natural sites. She has worked on plant macro-remains of Poland, Hungary, Slovakia, Greece, Germany, Cyprus, Israel, and Jordan.

Przemysław Mroczek (Ph.D. 2005, Maria Curie-Skłodowska University, Lublin, Poland) specializes in geological surveys of loess sediments and buried soils forming loess-paleosol sequences. His main research topics are the paleogeography of loess areas of central Europe in the period of individual cold and warm stratigraphic Quaternary units. His scientific interests focus on relief reconstruction of loess areas based on soil catena analyses, applied micromorphological methods (undisturbed thin sections), and laser diffraction (clastic sediments granulation). His entire professional career is connected with the Institute of Earth and Environmental Sciences at Maria Curie-Skłodowska University in Lublin.

Barna Páll-Gergely (Ph.D. 2015, Shinshu University, Japan) is a malacologist working mainly on the taxonomy, systematics, ecology, evolutionary biology, fossil history, and invasion biology of terrestrial molluscs of Europe and Southeast Asia. He is currently a Premium Postdoctoral Research Fellow of the Hungarian Academy of Sciences. Besides his main research subject (systematics revisions of southeastern Asian snails), he has been working on molluscs of European Quaternary and Holocene loess sediments for 10 years.

Tomasz Oberc (M.A. 2013, Jagiellonian University, Poland) is a younger researcher in the Centre for Mountains and Uplands Archaeology of the Institute of Archaeology and Ethnology PAS and a Ph.D. candidate in the Institute of Archaeology of Jagiellonian University in Kraków. He specializes in $2 \mathrm{D}$ and $3 \mathrm{D}$ documentation and modelling techniques, GIS, and statistics. His research concern is mainly the central European Neolithic, with its settlement patterns and demography being a main topic of his Ph.D. project. In the Institute of Archaeology and Ethnology PAS, he works as a lithic and use-wear analyst.

György Lengyel (Ph.D. 2006, University of Haifa, Israel) is currently an assistant professor in archaeology at the University of Miskolc. His research field is the Upper Palaeolithic with a special focus on how hunter-gatherer ecology formed the archaeological record. $\mathrm{He}$ is also involved with lithic technology, experimental knapping, and Epipalaeolithic research of the Near East.

\section{ORCID}

Jarosław Wilczyński (D) http://orcid.org/0000-0002-9786-0693 Ondrej Žaár (D) http://orcid.org/0000-0001-6432-490X

Adrián Nemergut (D) http://orcid.org/0000-0002-4176-1733

Bernadeta Kufel-Diakowska (D) http://orcid.org/0000-0002-1316-6216

Magdalena Moskal-del Hoyo (iD http://orcid.org/0000-0003-3632-7227

Przemystaw Mroczek (1) http://orcid.org/0000-0003-2702-5577

Barna Páll-Gergely (1D) http://orcid.org/0000-0002-6167-7221

Tomasz Oberc (D) http://orcid.org/0000-0002-0186-261X

György Lengyel (D) http://orcid.org/0000-0002-7803-3043

\section{References}

Banks, W. E., J. Zilhaỡ, F. d'Errico, M. Kageyama, A. Sima, and A. Ronchitelli. 2009. "Investigating Links Between Ecology and Bifacial Tool Types in Western Europe During the Last Glacial Maximum." Journal of Archaeological Science 36: 2853-2867.

Bárta, J. 1967. "O Kilku "Luźnych" Znaleziskach Paleolitycznych ze Słowacji." Acta Archaeologica Carpathica 9: 39-47.

Bárta, J. 1986. "Výskumná Správa 11615/86." Unpublished manuscript, Archive of Institute of Archaeology SAS, Nitra, Slovak Republic.

Bárta, J. 1988. "Trenčianske Bohuslavice un Habitat Gravettien en Slovaquie Occidentale." L'Anthropologie 92 (4): 173-182.

Bennet, J. L. 1999. "Thermal Alternation of Buried Bone." Journal of Archaeological Science 26: 1-8.

Beresford-Jones, D. G., K. Johnson, A. G. Pullen, A. J. E. Pryor, J. Svoboda, and M. K. Jones. 2010. "Burning Wood or Burning Bone? A Reconsideration of Flotation Evidence from Upper Palaeolithic (Gravettian) Sites in the Moravian Corridor." Journal of Archaeological Science 37: 2799-2811.

Binford, L. R. 1981. Bones: Ancient Men and Modern Myths. New York: Academic Press.

Brock, F., T. Higham, P. Ditchfield, and C. Bronk Ramsey. 2010. "Current Pretreatment Methods for AMS Radiocarbon Dating at the Oxford Radiocarbon Accelerator Unit (ORAU)." Radiocarbon 52: $103-12$.

Cichocki, O., B. Knibbe, and I. Tillich. 2014. "Archaeological Significance of the Palaeolithic Charcoal Assemblage from KremsWachtberg." Quaternary International 351: 163-171.

Clark, P. U., A. S. Dyke, J. D. Shakun, A. E. Carlson, J. Clark, B. Wohlfarth, J. X. Mitrovica, S. W. Hostetler, and A. M. Mccabe. 2009. "The Last Glacial Maximum." Science 325: 710-714.

Czernik, J., and T. Goslar. 2001. "Preparation of Graphite Targets in the Gliwice Radiocarbon Laboratory for AMS 14C Dating." Radiocarbon 43 (2A): 283-91.

Davies, W., and R. Hedges. 2005. "Dating the Middle-To-Upper Palaeolithic Transition: A New Chronometric Framework." In Pleistocene Environments and Archaeology of the Dzerava Skala Cave, Lesser Carpathians, Slovakia, edited by L. Kaminska, J. K. Kozłowski, and J. Svoboda, 59-66. Polska Akademia Umiejętności: Kraków.

Dobosi, V. T., and I. Vörös. 1987. "The Pilisszántó I. Rock-Shelter Revision." Folia Archaeologica 38: 7-64.

Goslar, T. 2015. "Description of Procedures of AMS 14C Dating Used in the Poznań Radiocarbon Laboratory." Unpublished manuscript available on the Poznan Radiocarbon Laboratory web page: https:// radiocarbon.pl/wp-content/uploads/2018/07/procedure_ams_prl. doc, accessed on 14.12.2019.

Goslar, T., J. Czernik, and E. Goslar. 2004. "Low-energy ${ }^{14} \mathrm{C}$ AMS in Poznań Radiocarbon Laboratory, Poland." Nuclear Instruments and Methods in Physics Research Section B: Beam Interactions with Materials and Atoms 223-224: 5-11.

Gramova, V. 1950. Determination Key to Mammals Of USSR Based on Postcranial Bones. Part 1. Determination Based on Long Bones. Moskwa-Leningrad: Izdatel'stvo Akademii Nauk SSSR. [in Russsian].

Greguss, P. 1955. Xylotomische Bestimmung der Heute Lebenden Gymnospermen. Budapest: Akadémiai Kiadó.

Haesaerts, P., F. Damblon, M. Bachner, and G. Trnka. 1996. "Revised Stratigraphy and Chronology of the Willendorf II Sequence, Lower Austria." Archaeologia Austriaca 80: 25-42.

Hauck, T. C., J. Rethemeyer, P. Rentzel, P. Schulte, S. Heinze, Á Ringer, J. Richter, W. Chu, F. Lehmkuhl, and O. Vogels. 2016. "Neanderthals or Early Modern Humans? A Revised 14C Chronology and Geoarchaeological Study of The Szeletian Sequence in Szeleta Cave 
(Kom. Borsod-Abaúj-Zemplén) in Hungary." Archäologisches Korrespondenzblatt 46 (3): 271-290.

Haynes, G. 1980. "Evidence of Carnivore Gnawing on Pleistocene and Recent Mammalian Bones." Paleobiology 6 (3): 341-351.

Haynes, G. 1983. "A Guide for Differentiating Mammalian Carnivore Taxa Responsible for Gnaw Damage to Herbivore Limb Bones." Paleobiology 9 (2): 164-172.

Händel, M. 2017. "The Stratigraphy of The Gravettian Sites at Krems." Quartär 64: 129-155.

Horsák, M., L. Juřičková, and J. Picka. 2013. Měkkýši České a Slovenské Republiky. Molluscs of the Czech and Slovak Republics. Zlín: Nakladatelství Kabourek.

Hughes, P. D., and P. L. Gibbard. 2015. "A Stratigraphical Basis for the Last Glacial Maximum (LGM)." Quaternary International 383: 174-185.

Hughes, A. L. C., R. Gyllencreutz, Ø. S. Lohne, J. Mangerud, and J. I. Svendsen. 2016. "The Last Eurasian Ice Sheets - A Chronological Database and Time-Slice Reconstruction, DATED-1." Boreas 45: $1-45$.

Kaczanowska, M., and J. K. Kozłowski. 1976. "Studia Nad Surowcami Krzemiennymi Południowej Części Wyżyny KrakowskoCzęstochowskiej." Acta Archaeologica Carpathica 16: 201-219.

Kaminská, L. 2014. Staré Slovensko 2. Paleolit a Mezolit. Nitra: Archeologický ústav SAV.

Kaminská, L., J. K. Kozłowski, and P. Škrdla. 2011. "New Approach to The Szeletian-Chronology and Cultural Variability." Eurasian Prehistory 8 (1-2): 29-49.

Kasztovszky, Z., and A. Prrichystal. 2018. "An Overview of The Analytical Techniques Applied to Study The Carpathian Obsidians." Archeometriai Mühely 15 (3): 187-196.

Kazior, B., J. K. Kozłowski, and K. Sobczyk. 1998. "Lithic Inventory.” In Complex of Upper Palaeolithic Sites Near Moravany, Western Slovakia, Vol. II, Moravany Lopata II (Excavations 1993-1996), edited by J. K. Kozłowski, 43-83. Jagiellonian University: Kraków.

Kerney, M. P., R. A. D. Cameron, and J. H. Jungbluth. 1983. Die Landschnecken Nord- und Mitteleuropas. Ein Bestimmungsbuch für Biologen und Naturfreunde. Hamburg/Berlin: Parey.

Klein, R. G., and K. Cruz-Uribe. 1984. The Analysis of Animal Bones from Archaeological Sites. Chicago: University of Chicago Press.

Klíma, B. 1963. Dolní Věstonice. Výzkum Tábořiště Lovců Mamutů v Letech 1947-1952. Praha: Československé akademie věd.

Klíma, B. 1990. Lovci Mamutu z Predmostí. Praha: Academia.

Kozłowski, J. K. 2013. "Raw Materials Procurement in the Late Gravettian of the Carpathian Basin." In The Lithic Raw Material Sources and the Interregional Human Contacts in The Northern Carpathian Regions, edited by Z. Mester, 63-85. Kraków/Budapest: Polska Akademia Umiejętności.

Lázničková-Galetová, M. 2011. "Analysis of Personal Ornaments." In Pavlov. Excavations 2007-2011. The Dolní Věstonice Studies 18, edited by J. Svoboda, 245-249. Brno: Archeologický ústav AV ČR.

Lengyel, G. 2014. "Distant Connection Changes from the Early Gravettian to the Epigravettian in Hungary." In Modes de Contacts et de Déplacements au Paléolithique Eurasiatique: Modes of Contact and Mobility During the Eurasian Palaeolithic, edited by M. Otte, and F. le Brun-Ricalens, 331-347. Liege: Université de Liege.

Lengyel, G. 2015. "Lithic Raw Material Procurement at BodrogkeresztúrHenye Gravettian Site, Northeast Hungary." Quaternary International 359-360: 292-303.

Lengyel, G. 2016. "Reassessing the Middle and Late Upper Palaeolithic in Hungary.” Acta Archaeologica Carpathica 51: 47-66.

Lengyel, G. 2018. "Lithic Analysis of the Middle and Late Upper Palaeolithic in Hungary." Folia Quaternaria 86: 5-157.

Lengyel, G., Z. Mester, and P. Szolyák. 2016. "The Late Gravettian and Szeleta Cave, Northeast Hungary." Quaternary International 406 (A): $174-183$

Lengyel, G., and J. Wilczyński. 2018. "The Gravettian and the Epigravettian Chronology in Eastern Central Europe: A Comment on Bösken et al. (2017)." Palaeogeography, Palaeoclimatology, Palaeoecology 506: 265-269.

Ložek, V. 1964. Quartärmollusken der Tschechoslowakei. Geologischen Zentralanstalt im Verlag der Tschechoslowakischen Akademie der Wissenschaften: Praha.

Lyman, R. L. 1994. Vertebrae Taphonomy. Cambridge: Cambridge University Press.
Marguerie, D., and J-Y Hunot. 2007. "Charcoal Analysis and Dendrology: Data from Archaeological Sites in North-Western France." Journal of Archaeological Science 34: 1417-1433.

Meng, S., and M. H. Hoffmann. 2009. “"Pupilla Loessica LOŽEK 1954 (Gastropoda: Pulmonata: Pupillidae) - "A Living Fossil" in Central Asia?" Quaternary Science Journal 58 (1): 55-69.

Mester, Z. 2013. "The Lithic Raw Material Sources and Interregional Human Contacts in The Northern Carpathian Regions: Aims and Methodology." In The Lithic Raw Material Sources and the Interregional Human Contacts in the Northern Carpathian Regions, edited by Z. Mester, 9-21. Kraków/Budapest: Polska Akademia Umiejętności.

Mester, Z. 2017. "Considérations sur le Szélétien en Hongrie: la Relation du Jankovichien au Szélétien Ancient." Anthropologie: International Journal of the Science of Man 55 (1-2): 75-92.

Mester, Z. 2018. "The Problems of the Szeletian as Seen from Hungary." Recherches Archéologiques Nouvelle Serie 9: 19-48.

Montet-White, A., ed. 1990. The Epigravettian Site of Grubgraben, Lower Austria: The 1986 and 1987 Excavations. ERAUL 40. Liège: l'Université de Liège.

Moreau, L. 2009. Geißenklösterle. Das Gravettien der Schwäbischen Alb im Europäischen Kontext. Tübingen: Kerns Verlag.

Moskal-del Hoyo, M., and J. K. Kozłowski. 2009. "Botanical Identification of Wood Charcoal Remains and Radiocarbon Dating - New Examples of the Importance of Taxonomical Identifications Prior to 14C Dating." Sprawozdania Archeologiczne 61: 253-271.

Moskal-del Hoyo, M., M. Wachowiak, and R. A. Blanchette. 2010 "Preservation of Fungi in Charcoal." Journal of Archaeological Science 37 (9): 2106-2116.

Nigst, P. R. 2012. The Early Upper Palaeolithic of the Middle Danube Region. Leiden: Leiden University Press.

Nigst, P. R., P. Haesaerts, F. Damblon, C. Frank-Fellner, C. Mallol, B. Viola, M. Götzinger, L. Niven, G. Trnka, and J.-J. Hublin. 2014 "Early Modern Human Settlement of Europe North of the Alps Occurred 43,500 Years Ago in a Cold Steppe-Type Environment." Proceedings of the National Academy of Sciences 111 (40): 1439414399.

Novák, M. 2004. "Gravettian Occupation in the Lower Layer of Kašov I." In The Gravettian Along the Danube. Proceedings of the Mikulov Conference, 20-12 November, 2002, edited by J. Svoboda, and L. Sedláčková, 217-242. Brno: Institute of Archeology, Academy of Science of the Czech Republic.

Novák, M. 2008. "Flint and Radiolarite Assemblages: Technology and Typology." In Petřkovice. On Shouldered Points and Female Figurines, edited by J. Svoboda, 70-42. Brno: Archeologický ústav AV ČR.

Novák, M. 2016. "Lithics on the Periphery. Variability in Assemblages from the Southern Edge and the Dolní Věstonice IIa Sub-Site (After 1990)." In Dolní Veštonice II. Chronostratigraphy, Paleoethnology, Paleoanthropology. The Dolní Věstonice Studies 21, edited by J. Svoboda, 246-272. Brno: Archeologický ústav AV ČR.

Nowak, M., M. Moskal-del Hoyo, A. Mueller-Bieniek, M. LityńskaZajac, and K. Kotynia. 2017. "Benefits and Weaknesses of Radiocarbon Dating of Plant Material as Reflected by Neolithic Archaeological Sites from Poland, Slovakia and Hungary." Geochronometria 44: 188-201.

Oliva, M. 1990. "La Signification des Pointes Foliacées Dans l'Aurignacien et Dans le Type de Míškovice." In Les Indutries a Pointes Foliacées du Paléolithique Supérieur Européen, edited by J. K. Kozłowski, 224-232. ERAUL 42. Liège: Université de Liège.

Oliva, M., ed. 2009. Milovice. Site of the Mammoth People Below the Pavlov Hills: the Question of Mammoth Bone Structures. Brno: Moravské zemské muzeum.

Oliva, M. 2016. Encyklopedie Paleolitu a Mezolitu Českých Zemí. Brno: Moravské zemské muzeum.

Olsen, S. L., and P. Shipman. 1988. "Surface Modification on Bone: Trampling vs Butchery." Journal of Archaeological Science 15 (5): 535-553.

Otte, M. 1981. Le Gravettien en Europe Centrale. Brugge: De Tempel.

Pales, L., and M. A. Garcia. 1981a. Atlas Ostéologique Pour Servir à L'identification des Mammifères du Quaternaire, II. Les Membres Herbivores - Tête-Rachis- Ceintures Scapulaire et Pelvienne. Paris: Éditions du CNRS.

Pales, L., and M. A. Garcia. 1981b. Atlas Ostéologique Pour Servir à L'identification des Mammifères du Quaternaire, II. Les Membres 
Carnivores, Homme - Tête- Rachis- Ceintures Scapulaire Et Pelvienne. Paris: Éditions du CNRS.

Patton, H., A. Hubbard, K. Andreassen, A. Auriac, P. L. Whitehouse, A. Stroeven, C. Shackleton, M. Winsborrow, J. Heyman, and A. Hall. 2017. "Deglaciation of the Eurasian Ice Sheet Complex." Quaternary Science Reviews 169: 148-172.

Piotrowska, N., and T. Goslar. 2002. "Preparation of Bone Samples in the Gliwice Radiocarbon Laboratory for AMS Radiocarbon Dating." Isotopes in Environmental and Health Studies 38 (4): 267-75.

Přichystal, A. 2013. Lithic Raw Materials in Prehistoric Times of Eastern Central Europe. Brno: Masaryk University.

Rasmussen, S. O., M. Bigler, S. P. Blockley, T. Blunier, S. L. Buchardt, H. B. Clausen, I. Cvijanovic. 2014. "A Stratigraphic Framework for Abrupt Climatic Changes During the Last Glacial Period Based on Three Synchronized Greenland Ice-Core Records: Refining and Extending the INTIMATE Event Stratigraphy." Quaternary Science Review 106: 14-28.

Reimer, P. J., E. Bard, A. Bayliss, J. W. Beck, P. G. Blackwell, C. Bronk Ramsey, C. E. Buck, et al. 2013. "IntCal13 and Marine13 Radiocarbon Age Calibration Curves 0-50,000 Years Cal BP." Radiocarbon 55 (4): 1869-1887.

Renard, C. 2011. "Continuity or Discontinuity in The Late Glacial Maximum of South-Western Europe: The Formation of the Solutrean in France." World Archaeology 43 (4): 726-743.

Richter, J. 2016. "Leave at the Height of the Party: A Critical Review of the Middle Paleolithic in Western Central Europe from its Beginnings to its Rapid Decline." Quaternary International 411 (A): 107-128.

Schweingruber, F. H. 1990. Anatomie Europäischer Hölzer. BernStuttgart: Paul Haupt Berne und Stuttgart Publishers.

Shipman, P., G. Foster, and M. Schoeninger. 1984. "Burnt Bones and Teeth: An Experimental Study of Color, Morphology, Crysta Structure and Shrinkage." Journal of Archaeological Science 11: 307-325.

Shipman, P., and J. Rose. 1983. "Early Hominid Hunting, Butchering, and Carcass Processing Behaviors: Approaches to the Fossil Record." Journal of Anthropological Archaeology 2: 57-98.

Simán, K. 1990. "Considerations on the "Szeletian Unity”." In Feuilles de Pierre. Les Industries á Pointes Foliacées du Paléolithique Supérieur Européen, edited by J. K. Kozłowski, 189-198. ERAUL 42. Liège: Université de Liège.

Stiner, M. C., S. L. Kuhn, S. Weiner, and O. Bar-Yosef. 1995. "Differential Burning, Recrystallization, and Fragmentation of Archaeological Bone." Journal of Archaeological Science 22: 223-237.

Stroeven, A. P., C. Hättestrand, J. Kleman, J. Heyman, D. Fabel, O. Fredin, B. W. Goodfellow, et al. 2016. "Deglaciation of Fennoscandia." Quaternary Science Reviews 147: 91-121.

Sutcliffe, A. J. 1970. "Spotted Hyaena: Crusher, Gnawer, Digester and Collector Of Bones." Nature 227: 1110-1113.

Svoboda, J., ed. 1997. Pavlov I - Northwest. The Upper Paleolithic Burial and its Settlement Context. Brno: Archeologický ústav AV ČR.

Svoboda, J. 2003. "The Bohunician and the Aurignacian." In The Chronology of the Aurignacian and of the Transitional Technocomplexes. Dating, Stratigraphies, Cultural Implications. Trabalhos de Arqueologia 33, edited by J. Zilhão, and F. d'Errico, 123-131. Lisboa: Instituto Portugês de Arqueologia.

Svoboda, J., ed. 2005. Pavlov I - Southeast. A Window Into the Gravettian Lifestyles. Brno: Archeologický ústav AV ČR.

Svoboda, J. 2007. "The "Gravettian on the Middle Danube."." Paleo 19: 203-220.

Svoboda, J., ed. 2016. Dolní Věstonice II. Chronostratigraphy, Paleoethnology, Paleoanthropology. Dolnověstonické studie, 21 . Brno: Archeologický ústav AV ČR.

Svoboda, J., Š Hladilova, I. Horaček, J. Kaiser, M. Králík, J. Novák, M. Novák, et al. 2015. "Dolní Vestonice IIa: Gravettian
Microstratigraphy, Environment, and the Origin of Baked Clay Production in Moravia.” Quaternary International 359: 195-210.

Svoboda, J., and M. Novák. 2004. "Eastern Central Europe After the Upper Pleniglacial: Changing Points of Observation." Archäologisches Korrespondenzblatt 34: 463-477.

Šída, P., M. Moravcová, D. Vokounová, and K. Blažková. 2015 Gravettské Osídlení v Lubné. Katalogy Nálezů do Roku 1960. Fontes Archaeologici Pragenses 42. Prague: Národní museum.

Škrdla, P. 2017. Moravia at the Onset of the Upper Paleolithic. Brno: Academy of Sciences of the Czech Republic, Institute of Archaeology.

Škrdla, P., L. Nejman, T. Rychtaříková, P. Nikolajev, and L. Lisá. 2014 "New Observations Concerning the Szeletian in Moravia." Quartär 61: 87-101.

Théry-Parisot, I. 2002. "Fuel Management (Bone and Wood) During Thethe Lower Aurignacian in the Pataud Rock Shelter (Lower Palaeolithic Les Eyzies de Tayac, Dordogne, France). Contribution of Experimentation." Journal of Archaeological Science 29: 1415-1421.

Újvári, G., J. F. Kok, G. Varga, and J. Kovács. 2016. “The Physics of Wind-Blown Loess: Implications for Grain Size Proxy Interpretations in Quaternary Paleoclimate Studies.” Earth-Science Reviews 154: 247-278.

Verpoorte, A. 2002. "Radiocarbon Dating the Upper Palaeolithic of Slovakia: Results, Problems and Prospect." Archäologisches Korrespondenzblatt 32: 311-325.

Villa, P., F. Bon, and J. C. Castel. 2002. "Fuel, Fire and Fireplaces in The Palaeolithic of Western Europe." Review of Archaeology 23: 33-42.

Vlačiky, M., T. Michalík, M. Nývltová Fišáková, D. Nývlt, M. Moravcová, M. Králík, J. Kovanda, K. Péková, A. Přichystal, and A. Dohnalová. 2013. "Gravettian Occupation of the Beckov Gate in Western Slovakia as Viewed from the Interdisciplinary Research of the Trenčianske Bohuslavice - Pod Tureckom Site." Quaternary International 294: 41-60.

von Proschwitz, T., C. Schander, U. Jueg, and S. Thorkildsen. 2009. "Morphology, Ecology and DNA-Barcoding Distinguish Pupilla Pratensis (Clessin, 1871) from Pupilla Muscorum (Linnaeus, 1758) (Pulmonata: Pupillidae)." Journal of Molluscan Studies 75 (4): 315322.

Welter-Schultes, F. W. 2012. European non-Marine Molluscs, a Guide for Species Identification. Göttingen: Planet Poster Editions.

Wilczyński, J. 2016. "Variability of Late Gravettian Lithic Industries in Southern Poland: A Case Study of the Krakow Spadzista and Jaksice II Sites.” Quaternary International 406 (A): 129-143.

Wilczyński, J., T. Goslar, P. Wojtal, P. Oliva, U. B. Göhlich, W. AntlWeiser, P. Šída, A. Verpoorte, and G. Lengyel. 2020. "New Radiocarbon Dates for the Late Gravettian in Eastern Central Europe." Radiocarbon 62 (1): 243-259.

Wild, E. M., M. Teschler-Nicola, W. Kutschera, P. Steier, E. Trinkaus, and W. Wanek. 2005. "Direct Dating of Early Upper Palaeolithic Human Remains from Mladeč.” Nature, 332-335.

Willis, K., E. Rudner, and P. Sümegi. 2000. "The Full-Glacial Forests of Central and Southeastern Europe." Quaternary Research 53: 203-213.

Willis, K. J., and T. H. van Andel. 2004. "Trees or no Trees? The Environments of Central and Eastern Europe During the Last Glaciation." Quaternary Science Reviews 23 (23-24): 236-2387.

Wojtal, P., J. Wilczyński, Z. M. Bocheński, and J. Svoboda. 2012. "The Scene of Spectacular Feasts: Animal Remains from Pavlov I South-East, The Czech Republic." Quaternary International 252: 122-141.

Wojtal, P., J. Wilczyński, K. Wertz, and J. Svoboda. 2018. “The Scene of a Spectacular Feast (Part II): Animal Remains From Dolní Vestonice II, The Czech Republic.” Quaternary International 466: 194-211.

Žaár, O. 2007. "Gravettienska Stanice v Trenčianskich Bohuslavicach." Unpublished MA thesis, Filozofická Fakulta, Univerzita Konštantína Filozofa v Nitre. Nitra. 